\title{
Early Pennsylvanian Paleotopography and Depositional Environments, Rock Island County, Illinois
}

Richard L. Leary C. Brian Trask

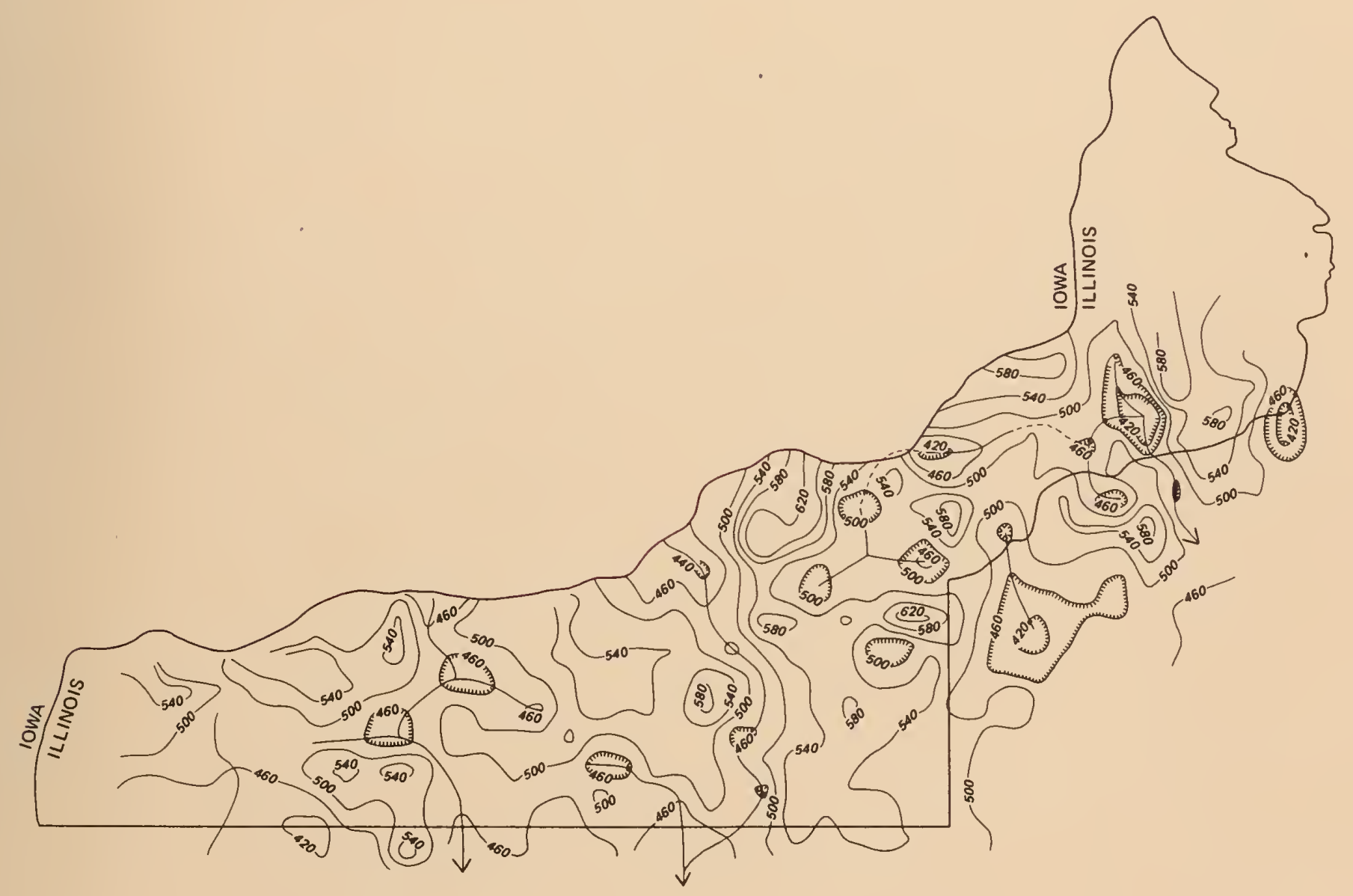

Nineteenth Annual Meeting, North-Central Section of the Geological Society of America Northern Illinois University, De Kalb, Illinois, April 25-27, 1985

Sponsored by the Illinois State Geological Survey 



\section{Early Pennsylvanian Paleotopography and Depositional Environments, Rock Island County, Illinois}

Richard L. Leary

Illinois State Museum

Springfield, Illinois 62706

C. Brian Trask

Illinois State Geological Survey

Champaign, Illinois 61820

ISGS Guidebook 18

Illinois State Geological Survey

Morris W. Leighton, Chief

Natural Resources Building

615 East Peabody Drive

Champaign, Illinois 61820 
Digitized by the Internet Archive in 2012 with funding from University of Illinois Urbana-Champaign 


\section{WARNING: ACCESS TO THESE QUARRIES IS RESTRICTED!!}

Persons entering without permission are subject to arrest and fines! Primarily due to OSHA (Occupational Safety and Health Administration) and MSHA (Mine Safety and Health Administration) federal regulations and insurance requirements, ALL persons entering property associated with quarries and mines MUST have WRITTEN PERMISSION and MUST WEAR hard hats, safety goggles, and steel-toed shoes and meet all other current federal safety regulations.

WRITTEN permission MUST be obtained from the appropriate company PRIOR to entering the quarry property. Write well in advance of any planned visit to assure completion of necessary arrangements before the selected date.

Write to:

(Allied Stone Company quarry)

Mr. James O. Ellis, President

Moline Consumers

313 16th Street

Moline, IL 61265
(Collinson Stone Company quarry)

Mr. Richard DeShepper

3115 23rd Avenue

Moline, IL 61265 


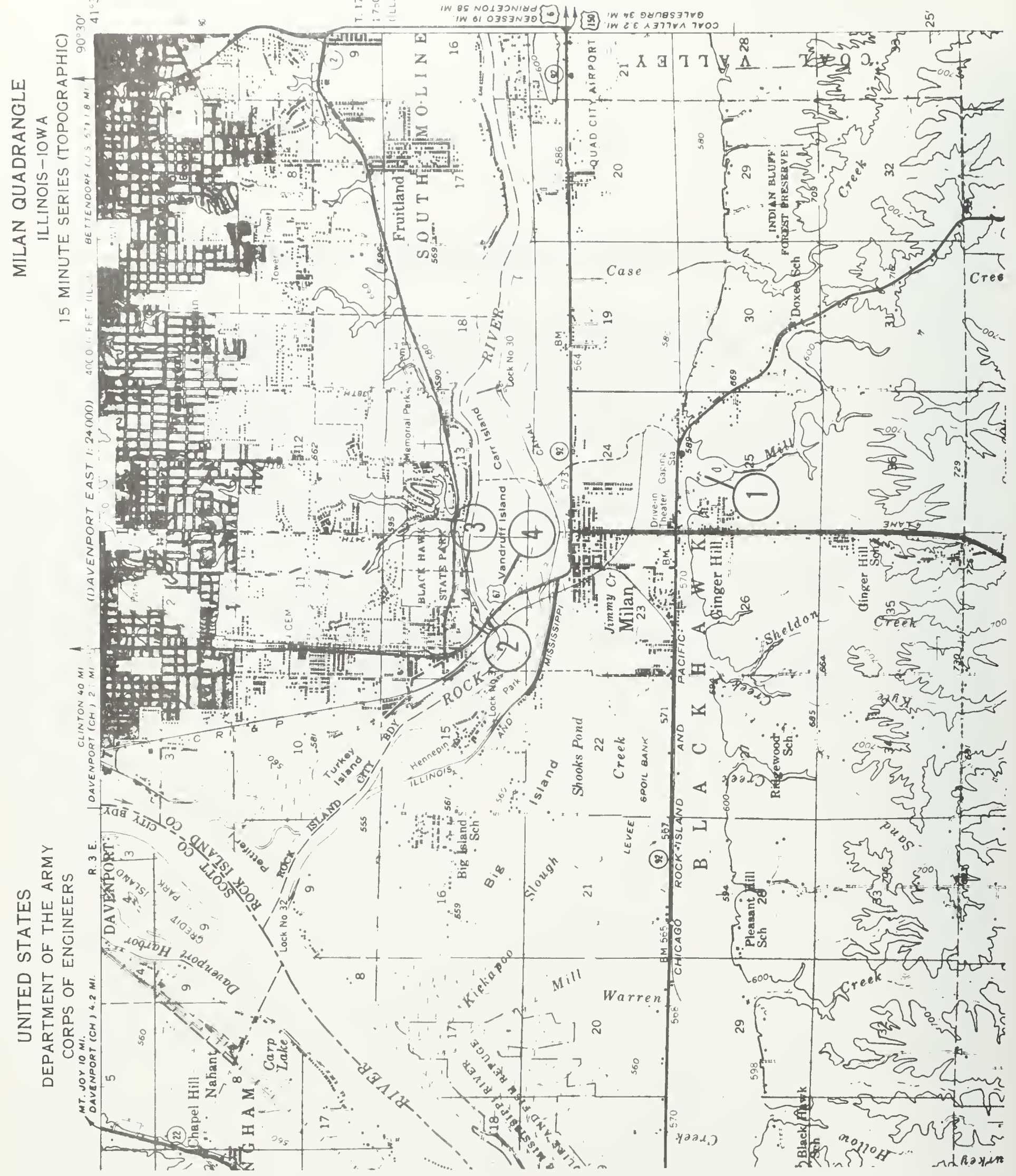




\section{EARLY PENNSYLVANIAN PALEOTOPOGRAPHY AND DEPOSITIONAL ENVIRONMENTS, ROCK ISLAND COUNTY, ILLINOIS}

\section{INTRODUCTION}

The Geological Society of America, NorthCentral Section, presents this one-day field trip to Rock Island County, Illinois, where you will have the opportunity to examine the prePennsylvanian unconformity, overlying sediments, and an early Pennsylvanian upland compression flora. The itinerary repeats a trip originally offered during the Ninth International Congress of Carboniferous Stratigraphy and Geology (IX-ICC) in 1979.

In recent years the nature and significance of the Mississippian-Pennsylvanian boundary have received considerable attention. In Illinois, as in much of the continental United States, the boundary is marked by a major unconformity. Extensive topographic relief developed on underlying strata prior to initial Pennsylvanian deposition. In parts of Illinois, especially along the margins of the Illinois Basin, erosion removed great thicknesses of pre-Pennsylvanian rocks (although some formations may have been thinner than equivalent strata in the deep part of the basin, or in fact, may never have been deposited).

In the Rock Island County area, the Pennsylvanian System overlies rocks ranging in age from Silurian to Devonian. Pre-Pennsylvanian topography was characterized by deep valleys, high hills, and some karst features. Although much of this topography can be examined only by means of drilling records, some higher elevations are now exposed. Several of these features will be seen on this field trip.

In recent years the senior author has collected a large number of well preserved early Pennsylvanian plant fossils in the Rock Island area. The fossils occur in rocks immediately overlying the erosional surface developed on Devonian carbonate strata (Cedar Valley and Wapsipinicon Limestones: Middle Devonian Series). The composition of the fossil plant assemblage is distinct from the more commonly preserved "coal-swamp flora."

The distinctive character of the flora has been considered the result of the distinctive environment that produced the flora. All flora from Rock Island County, and one from Brown County to the south, have been referred to as an "upland" flora.

This field trip will give geologists and paleobotanists an opportunity to examine the stratigraphic and paleotopographic setting of this flora. It will also provide an opportunity to discuss the nature of the flora, its relationship to the setting, and the paleoecological and evolutionary implications.

The guidebook itself is a reprint of Leary (1979). Some revisions have been made to update the guidebook with new exposures, new data, and new references. The geology of the field-trip area has been discussed by Leary (1981). Additional information concerning Labriscorpio alliedensis is also available (Leary, 1980). Phillips and Peppers (1984) have summarized regional paleoenvironmental patterns of coal swamps and discussed the effect of climate on coal occurrence in Euramerican coal fields.

Figure 6 has been revised to reflect new data. Now this illustration better shows the pre-Pennsylvanian paleovalleys in the Rock Island County area. Figure 7 shows the full extent of the channel exposed in the Allied Stone Company quarry. It also indicates that most of the fossil-bearing strata have now been removed by quarrying. Figure 8 has been updated to show a current (1984) cross section of a channel.

Russel A. Peppers at the Illinois State Geological Survey has examined the spore content of the coal from Stop 2. He believes (1984, personal communication) that this coal is lower Westphalian $\mathrm{A}$ in age. 


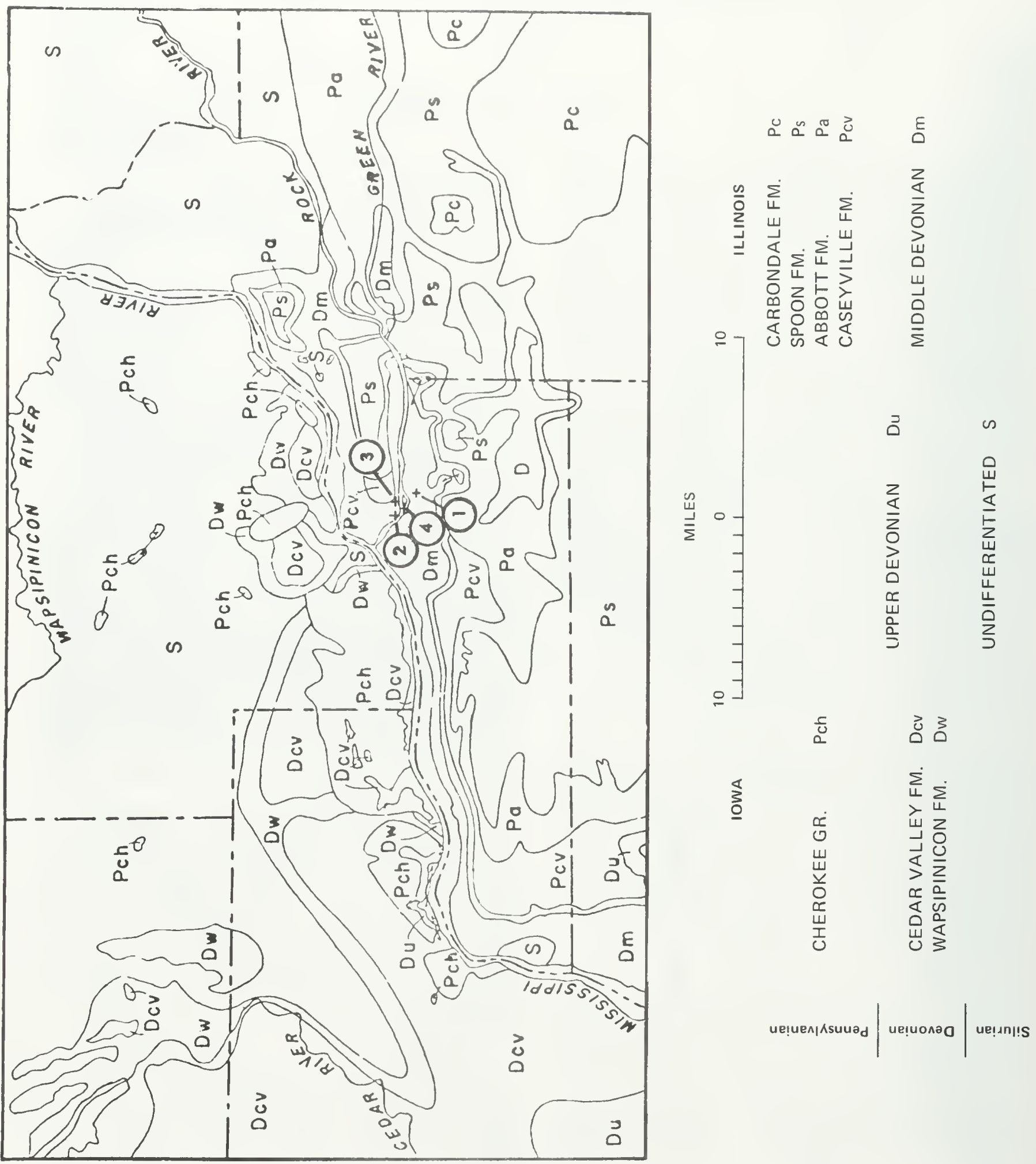

Figure 1. Geologic map of the Rock Island County area. Circled numbers are stops.

Base map from Edmund and Anderson, 1967. 


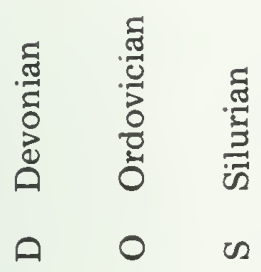

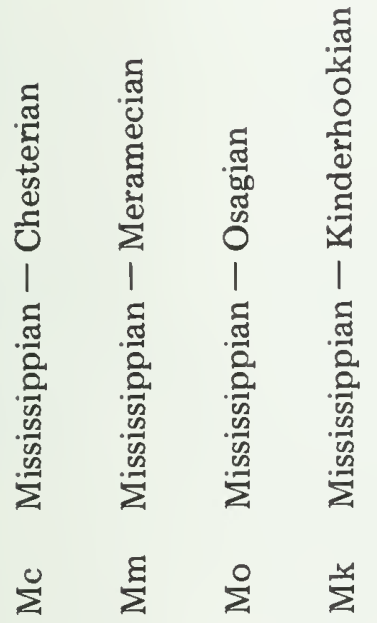

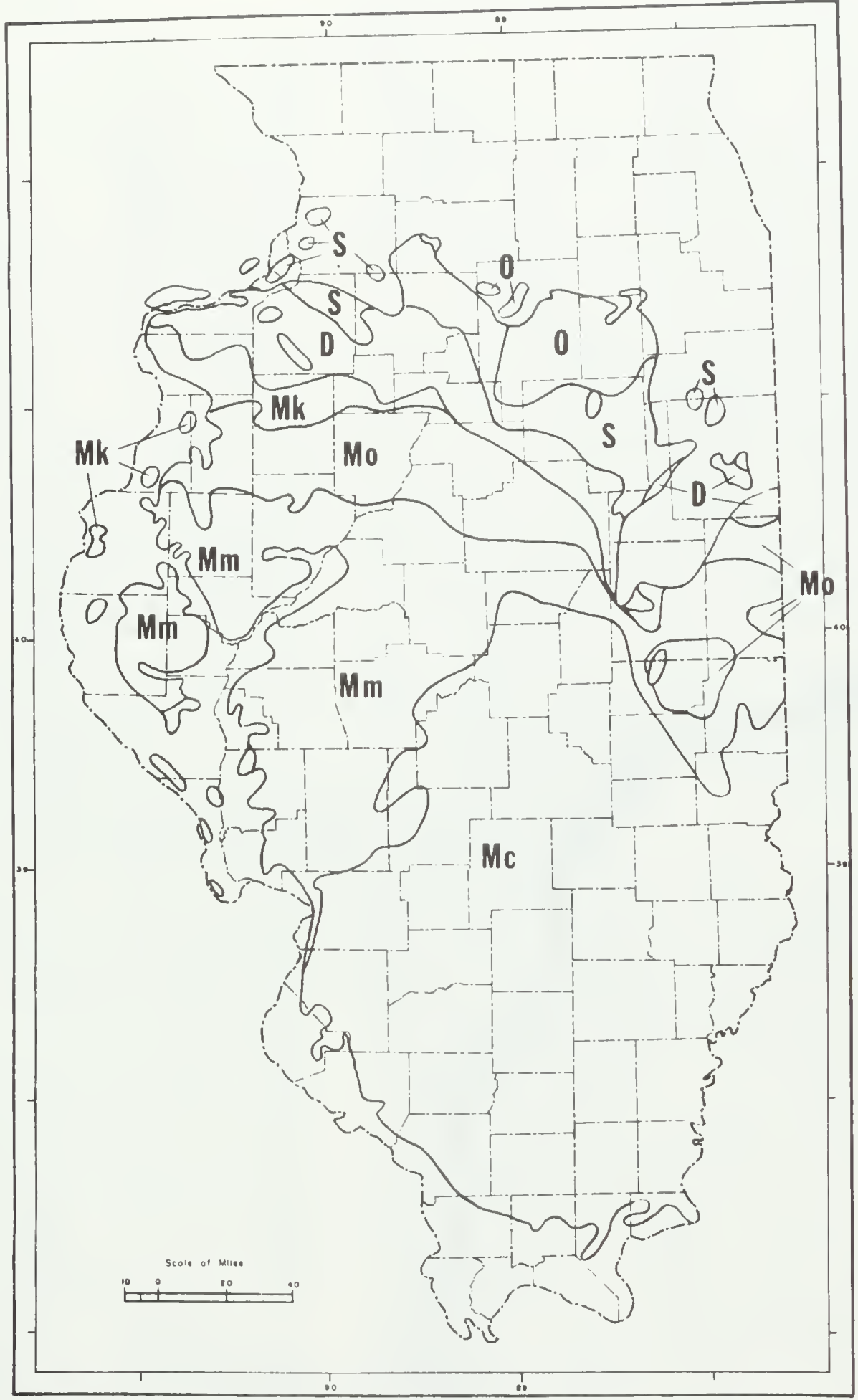

Figure 2. Generalized sub-Pennsylvanian geologic map of Illinois. (From Plate 2, Paleotectonic investigations of the Pennsylvanian System in the United States, McKee and Crosby, Coordinators, U.S.G.S. Prof. Paper 853.) 


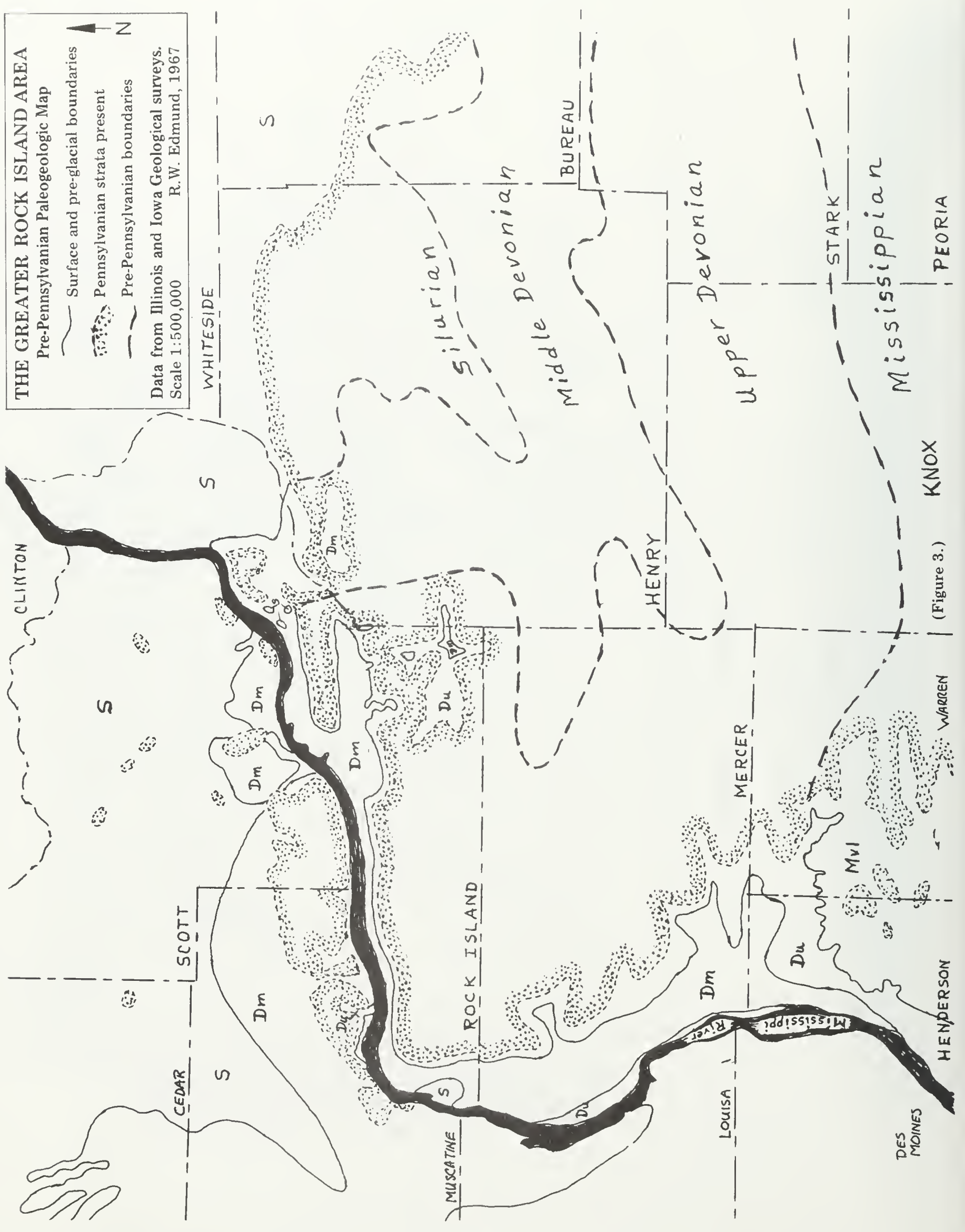




\section{GEOLOGICAL BACKGROUND}

Stratigraphy. In the Illinois Basin, Pennsylvanian strata overlie rocks ranging in age from Ordovician to Mississippian. The subPennsylvanian strata are primarily carbonates and had been exposed to subaerial erosion. Along the western margin of the Basin, Pennsylvanian rocks overlie older Mississippian rocks in the central part and Devonian rocks in the northwest (Reinertsen et al., 1974). Silurian and Ordovician strata underlie the Pennsylvanian along the northern margin (see geologic maps, Figs. 2, 3).

The relevant portion of the stratigraphic sequence in the Rock Island County area is illustrated in Figure 4. The major unconformity between the Devonian Cedar Valley Limestone and basal Pennsylvanian indicates a long period of erosion prior to earliest Pennsylvanian sedimentation. Because strata as young as the St. Louis Limestone (Valmeyeran = basal Visean) occur beneath the unconformity to the south, it is believed that the period of erosion came in Late Mississippian/Early Pennsylvanian (at the base of the European Namurian?).

Pre-Pennsylvanian topography. Major valleys are known to have drained eastward and southeastward across the pre-Pennsylvanian surface in the Mlinois Basin (Smith, 1941; Horberg, 1950). Similar valleys up to $140 \mathrm{~m}$ deep and up to $32 \mathrm{~km}$ wide are known from other parts of the Illinois Basin (Bristol and Howard, 1971).

As can be seen in several quarries and natural exposures in this area, the unconformity surface in the Rock Island County area was relatively flat. A few years ago, one could walk on the unconformity, a rolling limestone surface with a maximum relief of $2 \mathrm{~m}$ that was exposed in the Allied Stone Company quarry; unfortunately, it was destroyed by quarrying operations between 1975 and 1977. The flat upper surface of Devonian limestone can still be seen along the north and south walls of the Allied Stone Company quarry (Stop 4).

There are small knolls or "hills" on the limestone surface. One such knoll can be seen across the Rock River, north of the Allied quarry (Fig. 5). This one is only 3 to $4 \mathrm{~m}$ high. Another one, a higher limestone hill, is exposed northeast of the bridge where US 67 crosses the Rock River north of Vandruff Island and the Allied quarry. This hill is about $10 \mathrm{~m}$ above the river level which is the approximate elevation of the major portion of the unconformity here. Th is hill will be seen at Stop 2.

Although extensive areas of relatively low relief are present, some deep valleys were also developed prior to earliest Pennsylvanian sedimentation. One such valley occurs in southeastern Rock Island County (see map, Fig. 6).

A system of steep-sided, flat-bottomed channels was developed on Devonian limestone in the Rock Island County area. Although now largely destroyed by quarrying operations, these were observed in both the Allied Stone Company quarry and the Cleveland quarry. The primary trend of these channels was east-west (Fig. 7), but the locations were apparently controlled by jointing in the limestone. The exact nature of these channels has not been determined.

These channels were 4 to $6 \mathrm{~m}$ deep and 8 to $20 \mathrm{~m}$ wide (Fig. 8). They were filled with shale, mudstone, and occasional lenses or thin, discontinuous layers of sandstone. Occasional thin layers and masses of pyrite are also present with a few pyritized plant axes. The shale and mudstone are almost exclusively gray except for the upper portion which is sometimes thinly laminated black shale.

Similar channels have been exposed in several other quarries in the Rock Isl and County area (Fig. 9). Plant fossils comparable to those of the Allied Stone Company quarry were observed in the quarry at Cleveland, Henry County, Illinois, but these were poorly preserved and recent quarry ing operations have destroyed the fossil-bearing deposits.

Pre-Pennsylvanian karst topography. A karst topography apparently developed at the close of the Mississippian when the region was uplifted and exposed to subaerial erosion. At that time large areas of Silurian, Devonian, and Mississippian limestone strata were exposed on the western margin of the Mlinois Basin. Caves, filled with Pennsylvanian mud, silt, and sand, are known in the area. Sinkholes have been reported from both surface and subsurface data (McGinnis and Heigold, 1974). It is not known whether the channels exposed in the Allied Stone Company quarry drained into caves via sinkholes or into nearby deep valleys. 


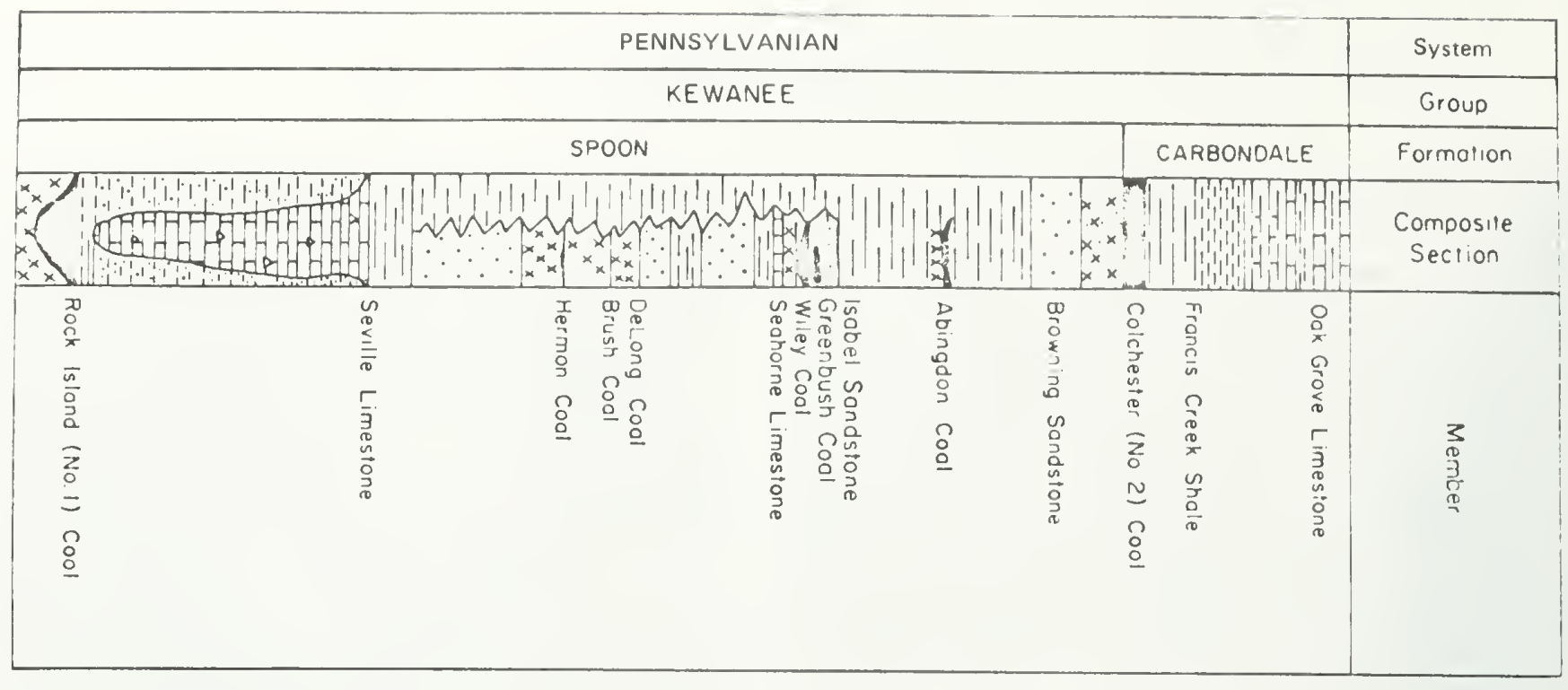
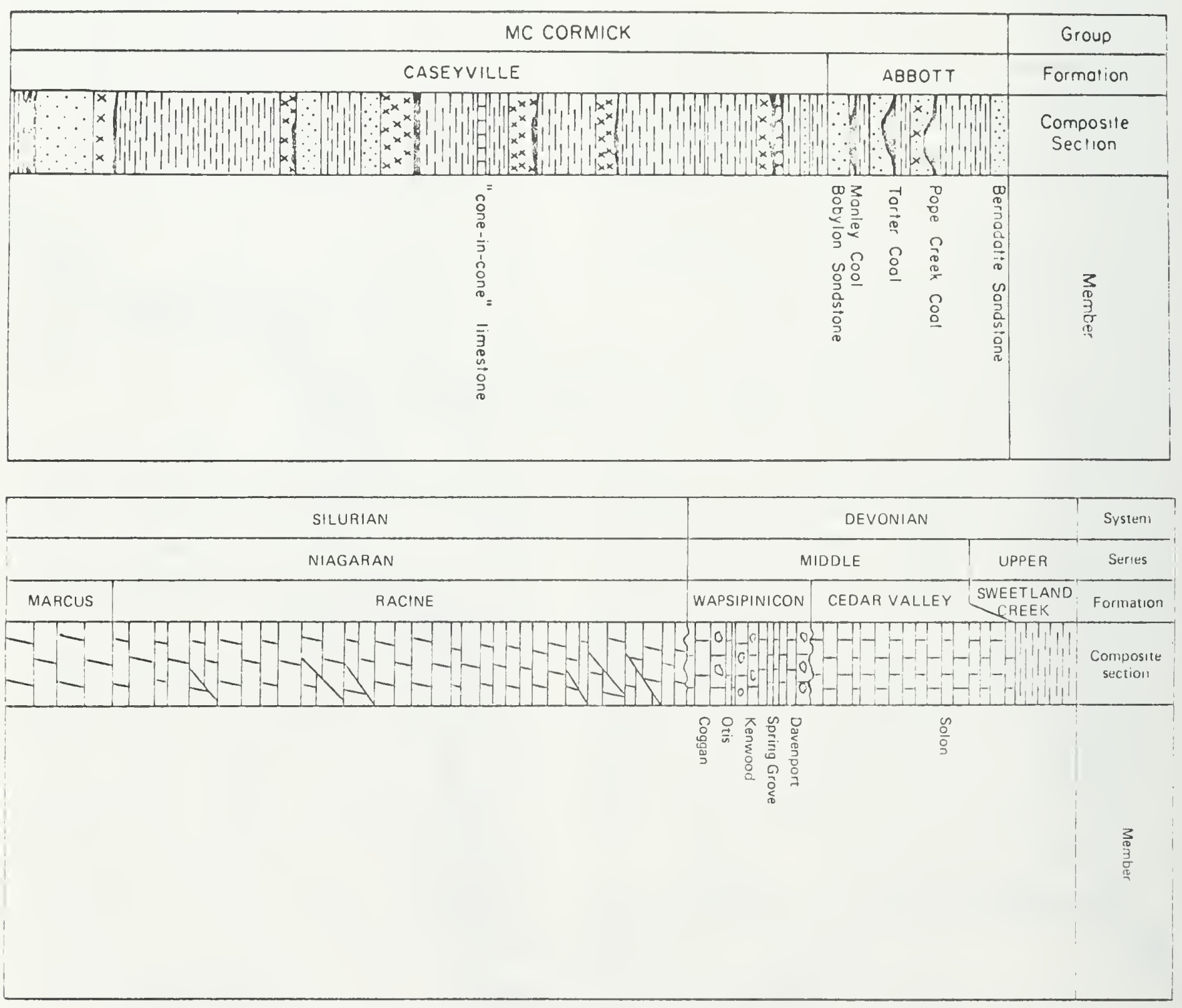

Figure 4. Composite section of Pennsylvanian, Devonian and Upper Silurian strata in the Rock Island County area. Pennsylvanian section from Searight and Smith, 1969. 


\section{PALEOBOTANICAL BACKGROUND}

Historical perspective. Several occurrences of Early Pennsylvanian (Late Namurian-Early Westphalian) plant fossils in western Mlinois have been known since the late 1800's (Worthen, 1873). In 1907, David White (1908) examined fossils from several localities in this area and published a brief report with a list of 14 fossil plant genera. Since that time, only sporadic collecting has been done and no significant collections are known other than those at the Illinois State Museum. The above, and broader aspects of compression plant fossil studies in the area of the Hlinois Basin, are reviewed by Phillips, Pfefferkorn, and Peppers (1973).

Description of significant "upland" taxa. The term "upland" has been used to designate distinctive nonswamp floras, but the actual paleoecology of such floras is not known. The "upland" plants grew on soils derived from limestone bedrock in western Illinois, and many were near stream banks and ultimately were deposited in stream channels with minimal transport.

Because the "upland" flora includes a number of genera which are unknown in coal swamps and are not well known, some general descriptions and illustrations are given.
Several species of Megalopteris occur in the floras of western Illinois. These range from large trilobed M. dawsoni (Hartt) Andrews (Pl. 1, Fig. 1) to smaller, pinnate (al ethopteroid) forms such as $M$. ovata Andrews (Pl. 2, Fig. 1). Other specimens (Pl. 2, Fig. 2) probably belonging to the megalopteroid group, if not to the genus Megalopteris, are similar to published figures and descriptions of such genera as Neriopteris (Newberry, 1873), Orthogoniopteris (Andrews, 1875) and Protoblechnum (Andrews, 1875). Differences between these genera and their relationships are not clear from the literature.

Lesleya foliage is similar to Megalopteris pinnules but consists of simple leaves (Pl. 1, Fig. 2). These leaves are greater than $30 \mathrm{~cm}$ long and $10 \mathrm{~cm}$ wide. The midvein is broad, though not as broad as that of Megalopteris; the lateral veins are curved and divide once or twice. Lesleya and Megalopteris are also separated on the basis of epidermal structures (Florin, 1933).

Mesocalamites (Pl. 3, Fig. 1) is distinguished from Calamites on the basis of the continuity of ribs across the nodes. Calamites ribs alternate whereas some ribs of Mesocalamites alternate and some are continuous. Mesocalamites is largely restricted to the Namurian, rarely extending into the Westphalian. Archaeocalamites,

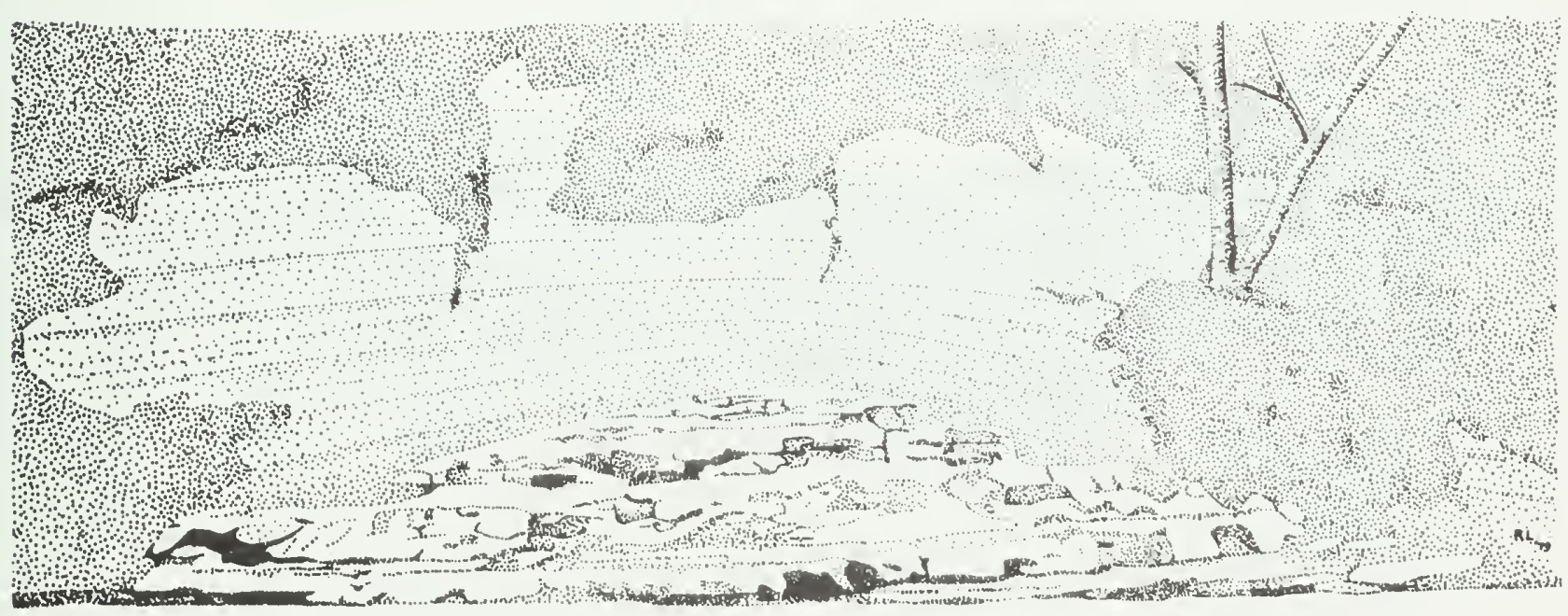

Figure 5. A limestone knoll exposed on the north side of the Rock River below the Watch tower, Black Hawk State Park. Sec. 14, T. 17 N., R. 2 W. 


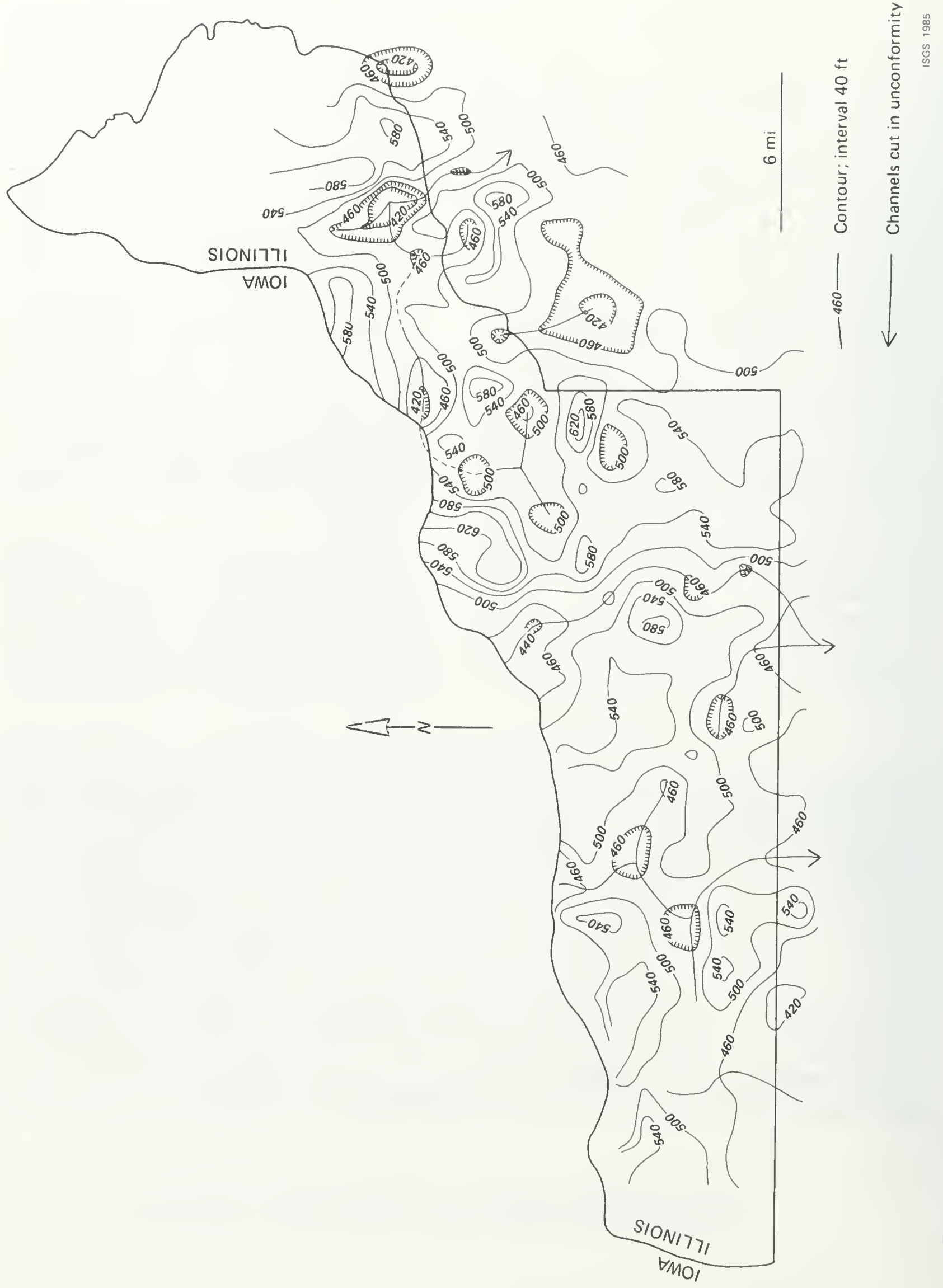




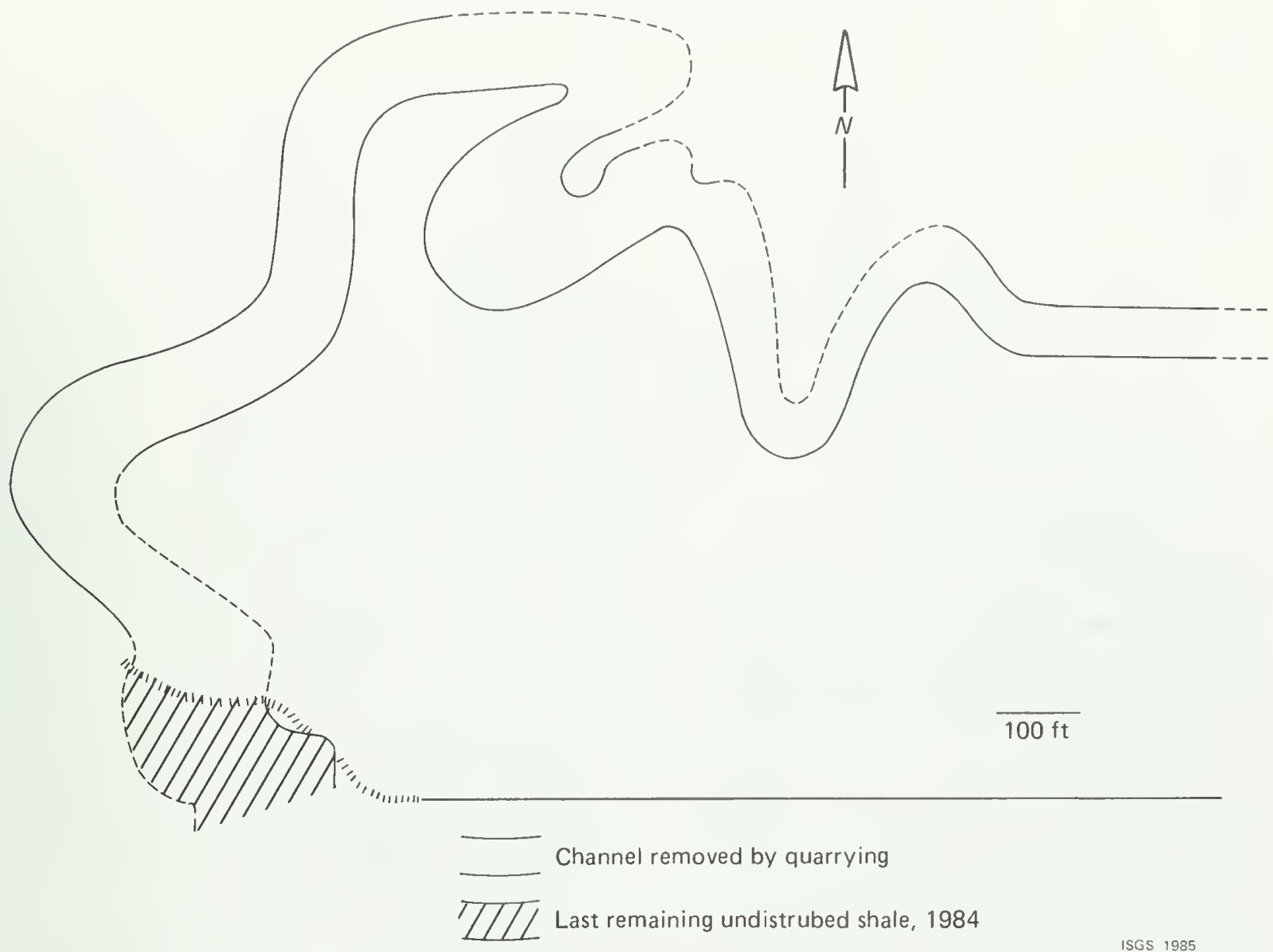

Figure 7. Channel filled with fossil-bearing shale, siltstone, and sandstone in the Allied Stone Company quarry.
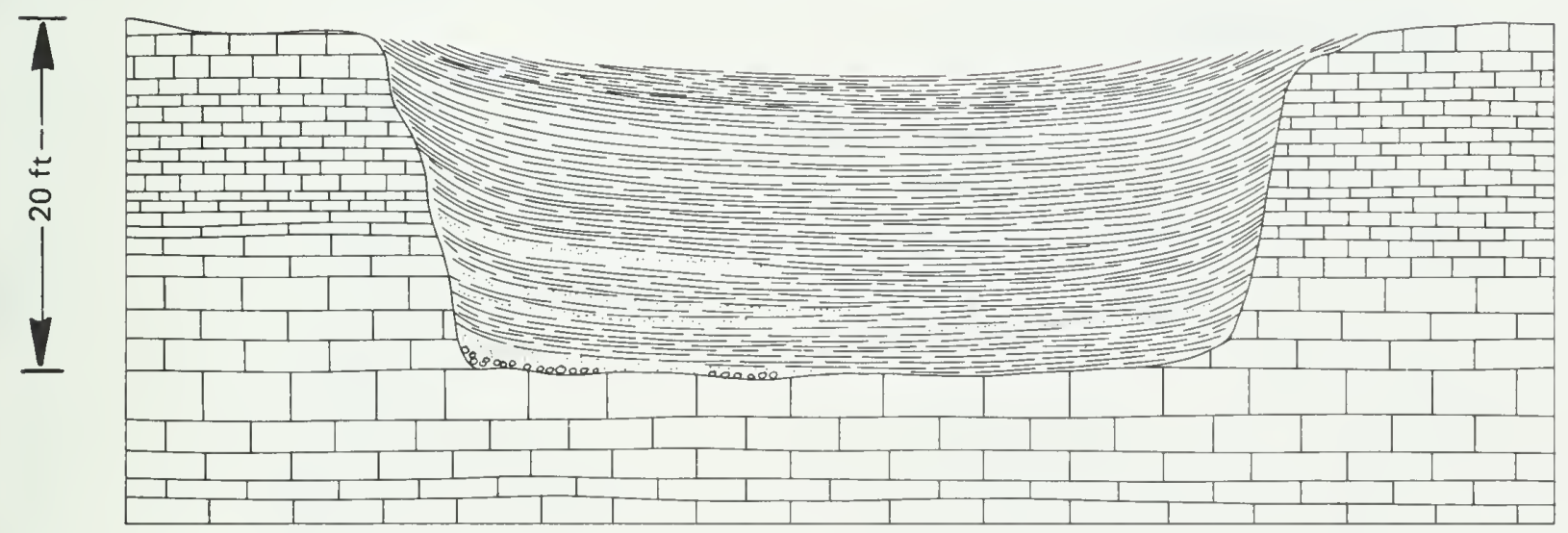

ISGS 1985

Figure 8. Cross section of a channel. 


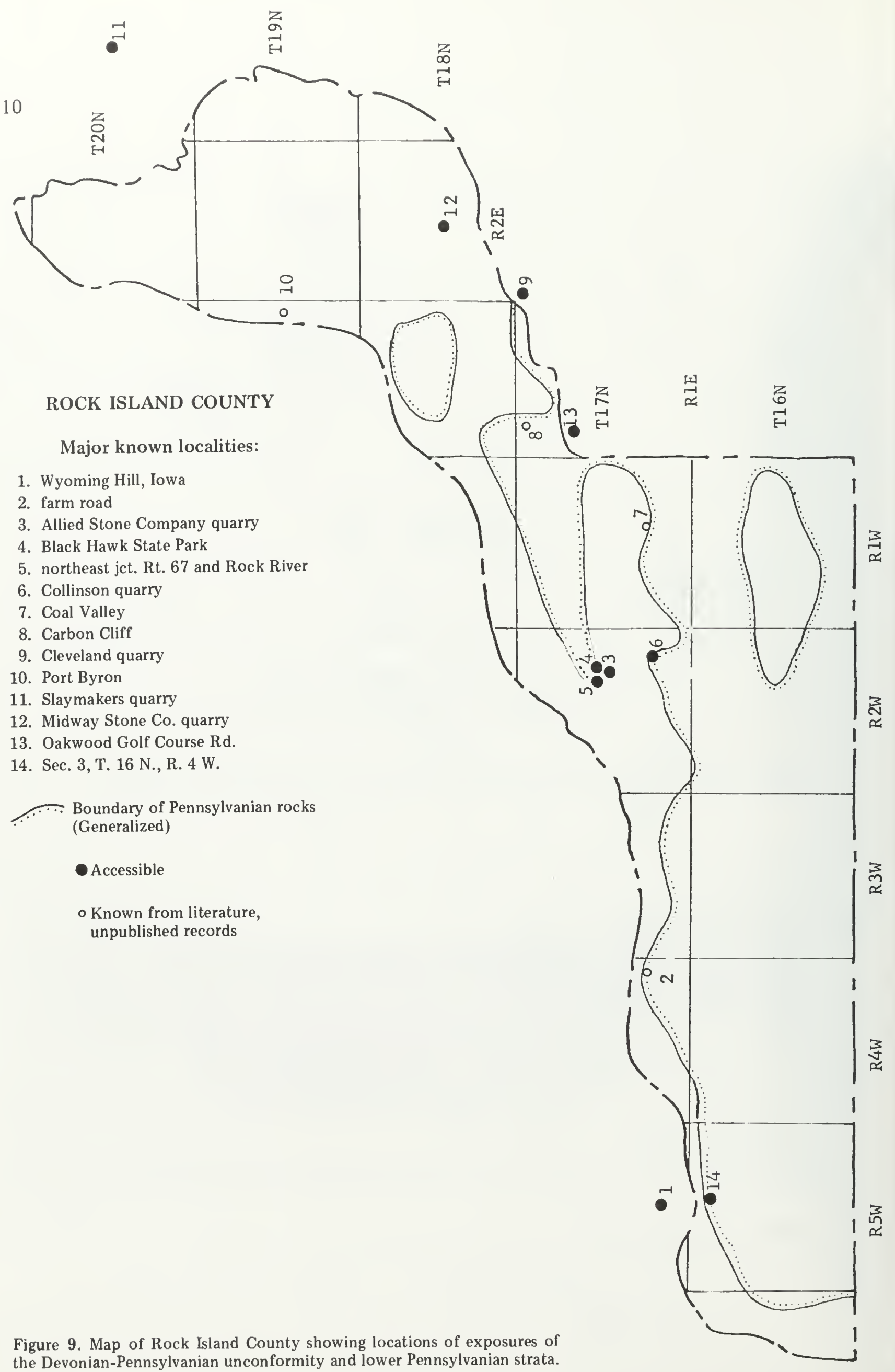


an older form, has all ribs continuous across the nodes. The correlation of various species of Mesocalamites/Calamites to species of foliage, Asterophyllites/Annularia, and fructifications, Calamostachys, is still not complete.

Lacoea (Pl. 3, Fig. 5) is a cone consisting of semicircular sporophylls which alternate on a thick axis. Lacoea and similar, perhaps synonymous, forms are known from a few localities but in distant parts of the world: Holland (Hirmer, 1940, 1941); Belgium (Stockmans and Williere, 1962); Czechoslovakia (Feistmantle, 1879); Germany (Hirmer, 1940); and China (Stockmans and Mathieu, 1957). Although Read (1946) suggested that Lacoea might be a pteridosperm, specimens from Brown County, nlinois, have permitted a reinterpretation; Lacoea is now considered a member of the Noeggerathiales (Leary, 1973). However, the broader natural affinities of the Noeggerathiales are not known. This order has been treated as a separate group or loosely allied with either the Pteridopsida or Sphenopsida (Boureau, 1964 ). The Noeggerathiales are well represented in the "upland" floras of western Ilinois.

Gulpenia (Pl. 3, Fig. 2), another member of the Noeggerathiales, is characterized by small, deeply lacerated leaves attached spirally to a thin axis. In compression, Gulpenia bears a superficial similarity to Sphenophyllum but the leaves clearly alternate.

Megalopteris is not known to occur outside North America (Arnold, 1934)* where it has been reported from the following localities:

St. John, New Brunswick

Rushville, Ohio

$$
\text { Dawson (1871), Stopes (1914) }
$$

Port Byron, Illinois

Andrews (1875), Cross (1962)

Wyoming Hill, Iowa

$$
\text { Lesquereux (1880) }
$$

Grand Ledge, Michigan

$$
\text { Noe (1925) }
$$

Saginaw, Michigan

$$
\text { Arnold (1934) }
$$

$$
\text { Arnold (1934) }
$$

*A single fragment from Britain reported as Megalopteris (Arber, 1904) is now referred to Lesleya (Leary, in press).
Putnam County, Indiana

Arnold (collected 1936, oral comm.)

Pictou, Canada

Bell (1940)

West Virginia

White (1913)

Greene County, Indiana

Canright (1959), Wood (1963)

Brown County, Hlinois

Leary and Pfefferkorn (1977)

Rock Island County, Mlinois

Leary $(1974 b, 1976$, this guidebooklet)

In almost half of these localities, Megalopteris occurs with a flora which is distinct from the common coal swamp flora. The Megalopteris floras appear to contain greater percentages of pteridosperms and Cordaites and smaller percentages of ferns and lycopods than do Early Pennsylvanian floras associated with coal seams ("swamp floras") (Phillips et al., 1974). White (1931, p. 275-276) suggested that Megalopteris and Lesleya are unique to uplands developed on carbonates. Recent studies by Cross supports this concept (personal communication). The flora associated with Megalopteris apparently grew on drier uplands underlain by limestone.

Environmental changes indicated in the Allied flora. Studies of the paleoecological differences in Mississippian-Pennsylvanian floras have shown that several paleoenvironments can be recognized (Peppers and Pfefferkorn, 1970, for summary, also Remy and Remy, 1977). At the top of the sequence in several channel fills in the Allied quarry, the flora is characterized by an overwhelming abundance of Mesocalamites with Lepidodendron and Psaronius; little else is present. This change in composition apparently represents a change from drier "upland" to wet lowland, or swamp, conditions as stream channels were filled with sediment and the water table correspondingly rose to near ground level. Tench ov (1976) described floral changes within a Carboniferous floral sequence of western Bulgaria and related these to continuous uplift of the basin. Changes in the elevation of the western margin of the nlinois Basin, relative to the central area of the Basin, may have brought about changes in floral composition in this area. 
Comparisons of "upland" floras. Recent studies of an Early Pennsylvanian flora from Brown County, Illinois (Fig. 10) (Leary, 1973, 1974a, 1974b, 1976; Leary and Pfefferkorn, 1977) have identified twenty-one genera of plants (Table 1). Among the most common are Lacoea, Sphenopteris, Cordaites, and Alethopteris. Megalopteris and Lesleya are also well represented. Thirty-two genera of foliage, fructifications, and stems have so far been identified from the Allied Stone Company quarry (Table 1). The most abundant taxa at this site are Megalopteris, Lesleya, Samaropsis, Cordaites, and Cardiocarpus.

The two floras (Table 1) have many genera in common; differences are in the relative abundance of certain genera and presence or absence of certain others. Arborescent lycopods are common in the nonswamp Rock Island flora but very rare in the Brown County flora; only one determinable specimen and two fragmentary specimens of Lepidodendron have been found at the latter site; Lepidophloios is absent from the Brown County locality and rare in the Allied quarry site. Lycopods are the dominant plants in most Lower and Middle Pennsylvanian coal swamp floras of the Illinois Basin (Phillips et al., 1974). Sphenopsids and Cordaites are more abundant in parts of the Rock Island flora than in the Brown County flora; ferns are more common in the the Brown County flora.

Although the ages of the two floras are probably not exactly the same, the differences in generic composition probably reflect environmental differences rather than age differences. The presence of a permanent body of water in the channels apparently permitted the growth on the drier sites in Rock Island of genera (e.g., Lepidodendron and Mesocalamites) common to coal swamps.

Comparison with European Floras. The flora exposed in the Allied Stone Company quarry is one of very few Namurian-age floras known in North America and provides a rare opportunity for comparison with floras of similar age in Europe. Analysis of the Illinois "upland" floras enables us to make comparisons with the "flozformend" (seam-forming) and "flozfern" (distant from the seam) floras of the European Namurian (Havlena, 1961). Numerous similarities exist between these as well as significant differences.

The greatest similarity appears to be with the flora of the Ostrava-Karvina coal district of Czechoslovakia (Sustra, 1928; Purkynova, 1970). Here, Havlena (1970) recognized several microenvironments within the Namurian hygrophile environment in addition to a major separation of the hygrophile and mesophile environments. The mesophile ("upland") flora described by Havlena from the Ostrava-Karvina coal district was present only as fragments (Havlena, 1971, p. 245) whereas preservation of the plants in the Allied quarry is excellent. 
TABLE 1

LIST OF GENERA PRESENT AT THE LOCALITIES IN

BROWN AND ROCK ISLAND COUNTIES, ILLINOIS

Lycophytina

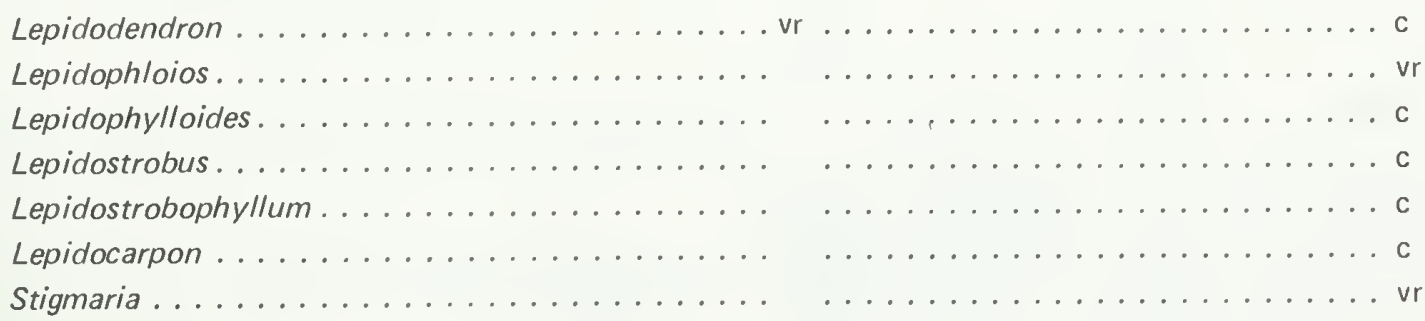

Sphenophytina

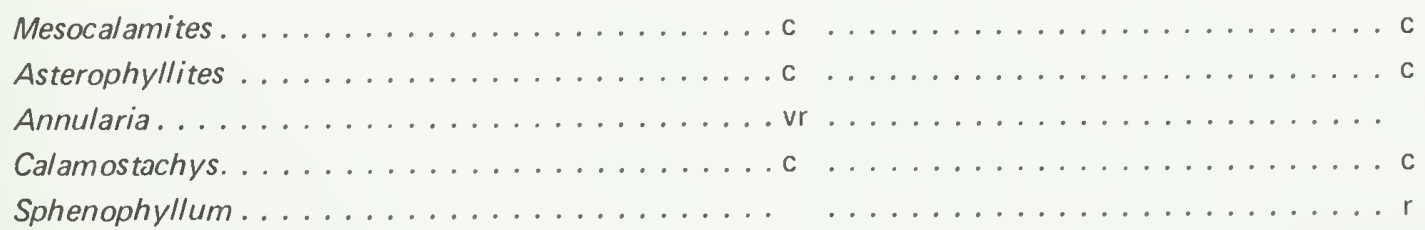

Filicophytina (Ferns)

Alloiopteris

Dactylotheca

Pteriodospermales

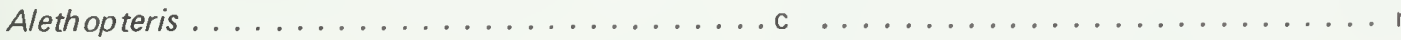

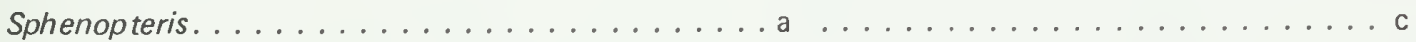

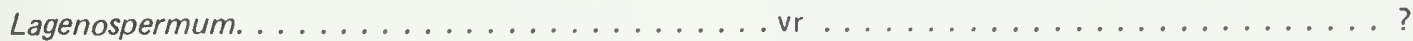

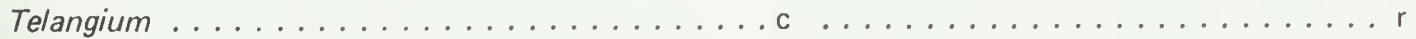

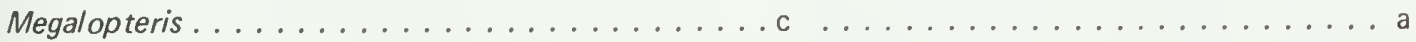

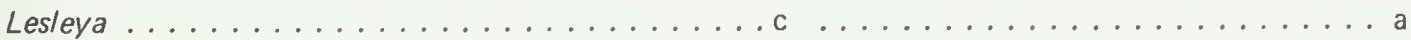

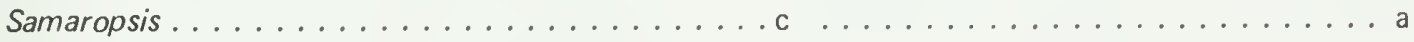

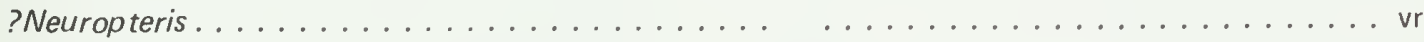

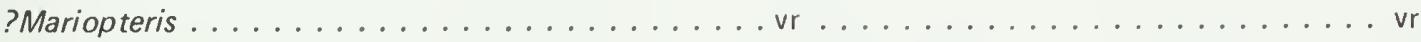

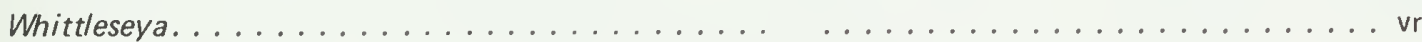

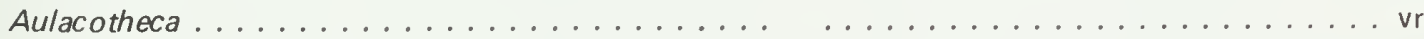

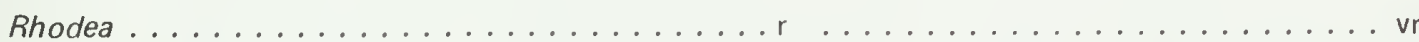

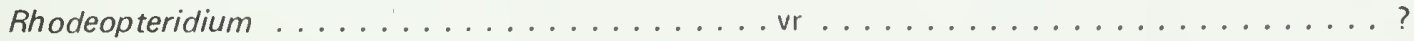

Noeggerathiales

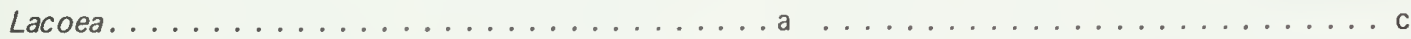

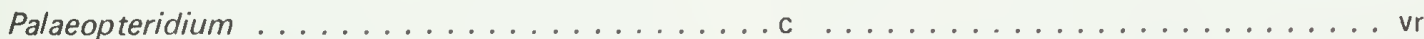

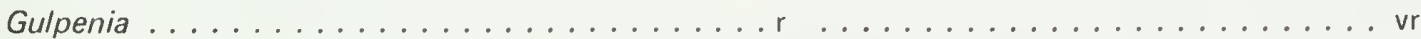

Cordaitales

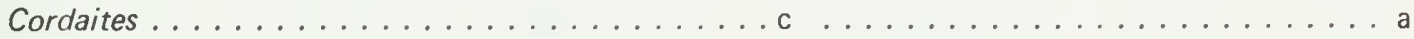

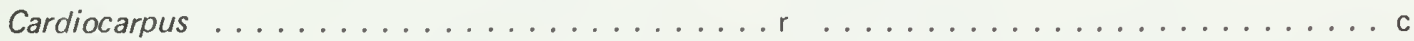

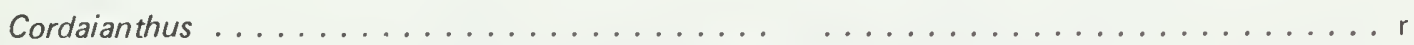

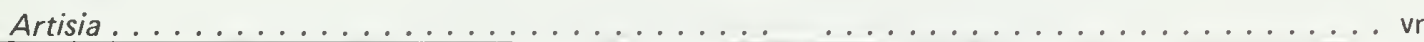

Approximate abundance indicated by the following:

$\mathrm{vr}=$ very $\operatorname{rare}(1,2)$

$r=\operatorname{rare}(3-5)$

$\mathrm{c}=$ common $(5.25$

$\mathrm{a}=$ abundant $(>25)$

Based upon 350 specimens from each locality. 
1 St. Louis, Mo.

2 Golden Eagle

3 Brown County

4 Monmouth

5 Wyoming Hill, Iowa

6 Cleveland quarry

7 Midway quarry

8 Port Byron

9 La Salle County

10

Channahon

11

Kankakee

12

Putnam County, Ind.

13

Green County, Ind.

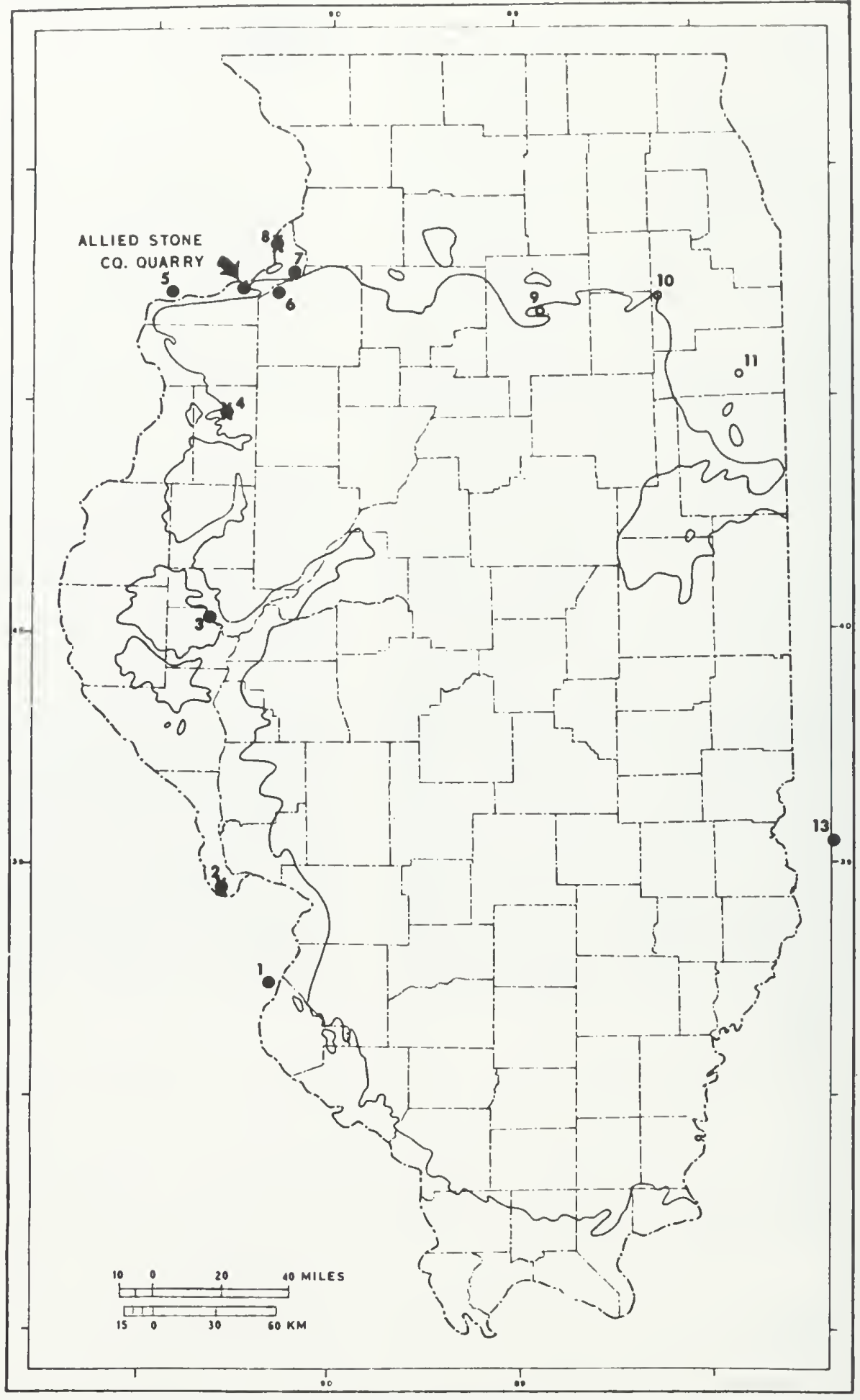

Figure 10. Map of reported localities of Early Pennsylvanian plant fossils on the margins of the Illinois (Eastern Interior) Basin.

Margin of Perinsylvanian strata

Locality no longer accessible
Existing locality

Spores only 
Stop 1: Collinson Stone Company Quarry.

\section{SE SE NE NW Sec. 25, T. 17 No., R. 2 W., Milan 7.5' Quadrangle.}

Caution: Do not approach the edge of the main quarry. Look where you step and watch what is above you on the upper level.

Exposures of Pleistocene, Pennsylvanian, and Devonian strata can be seen in this qualry.

Strata exposed by quarrying operations here include slightly more than $30 \mathrm{~m}$ of middle Devonian limestones that are divided into about $10 \mathrm{~m}$ of Wapsipinicon Limestone in the deeper part of the quarry and about $18 \mathrm{~m}$ of overlying Cedar Valley Limestone (Fig. 11). The limestones composing these two formations accumulated in warm shallow seas that covered the midcontinent region about 370 to 395 million years ago. Although initially it would appear that conditions of deposition were fairly consistent for long periods so that thick limestones could accumulate, a closer examination of the Wapsipinicon shows that it contains a considerable amount of brecciation. The brecciation has been interpreted as being the result of the removal of soluble beds, such as gypsum or salt. Their removal then caused collapse of overlying limestone layers. Significantly, gypsum is currently being mined from the Spring Grove Dolomite Member of the Wapsipinicon at Mediapolis, Iowa, less than 80 $\mathrm{km}$ to the southwest. If removal of an evaporite bed were the actual cause of brecciation, it would appear that the formation accumulated in a restricted basin of deposition, such as a large lagoon. The water temperature and salinity may have been high because there was limited open circulation with the deeper oceans nearby and conditions were right for the deposition of evaporite materials. The scarcity of fossil forms indicates that the water did not support abundant life. Since brecciation and contorted bedding is restricted to the Wapsipinicon, removal of the soluble evaporite materials must have preceded the deposition of the overlying Cedar Valley.

The Cedar Valley Limestone must have been deposited under much different conditions.
The absence of brecciation and contorted bedding and the presence of abundant fossil forms indicate that the seas were shallow, warm, and open to free circulation. (Fossil collecting is best from the bench upward.)

At the close of the Devonian Period, when seas withdrew from the midcontinent region, strata in this area were subjected to erosion before Mississippian seas advanced across the region. Although strata from this latter marine advance have not been identified from this vicinity, chert fragments from the overlying basal conglomerate of the Pennsylvanian Period contain fossil fragments indicative of the early and middle portions of the Mississippian time, indicating that Mississippian sedimentation did occur in this area. After Mississippian sedimentation ceased in this region, the land surface again stood above sea level and was so extensively eroded that all Mississippian rocks were removed, except for the relatively insoluble chert rubble. An uneven topography was developed; when shallow Early Pennsylvanian seas encroached upon the region, new sediments did not blanket all earlier strata. The higher hills and knobs of the older topography must have been low islands in the sea. Stream channels, sinkholes, and caves which developed on and in the old eroded surface were the first to receive earliest Pennsylvanian sediments consisting of sands, silts, and muds that later formed sandstone, siltstone, and shale. A description of the topography of this surface can be found under BACKGROUND, page 5 .

Pennsylvanian deposits noted at this quarry seem to be only sinkhole fillings, although as the quarry is expanded farther south and west, more extensive Pennsylvanian strata should be encountered. Because of slumping, the exact relations are not always visible; so it is possible that the Pennsylvanian strata in the southwestern part of the quarry highwall could be located in a shallow stream channel on the old surface.

Overburden exposed along the southwestern part of the quarry reveals possible Kansan and Yarmouthian deposits beneath Illinois, Sangamonian, Wisconsinan, and Holocene materials.*

* Modified from the I.S.G.S. Milan Guidebook, 1974. 


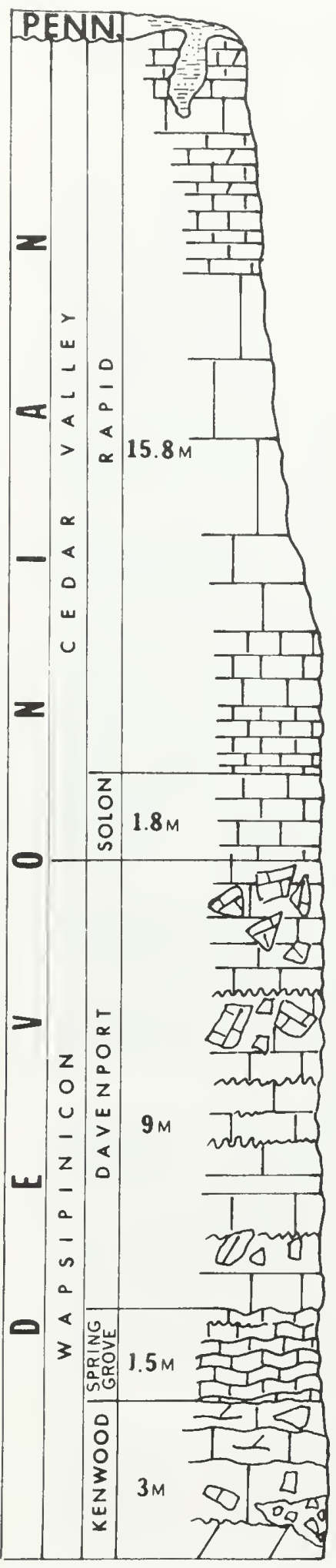

Sandstone, sandy greenish shale in solution cavities.

Limestone, gray to buff. Cystodictya, Stropheodonta, Spirifer. Bioherm with Hexagonaria, Cystphylluil, Favosites, Cladopora, and Atrypa common

Limestone, gray to buff, dolomitic, with abundant crinoids and some micro-conglomerate.

Many stromatoperoids and bryozoa with fossils 1 isted above.

Limestone, greenish-gray to buffish-gray, fine grained, argillaceous, massive, weathers readily, oblique joints prominent.

Relatively few fossils.

Fossils present but not abundant.

Limestone, greenish-gray to grayish-brown, fine grained, argillaceous to shaley partings, weathers easily, fossiliferous. Atrypa, Strophodonta, Leptostrophia, Chonetes, Spirifer, Schizophoria, Pentamerello, Heliophyllum, Cystiphyllum, Favosites, Productella, also crinoidal.

Limestone, grayish-brown, sublithographic to fine grained, weathers with brown splotches, very fossiliferous. Astreospongia, Stromatoporoids, Heliophyllum, Favosites.

Limestone, very light gray, 1ithographic to sublithographic, brecciated, pyritic sandy streaks. Grades down to brownish-gray lithographic limestone.

Limestone, very light gray to light gray, lithographic to sublithographic, hard, brecciated to bedded.

Limestone, brown to brownish-gray, sublithographic with thin light-colored laminae.

Limestone, brownish-gray, sublithographic, fractures often calcite filled, some pyrite.

Limestone, gray, lithographic, contorted bedding, brecciated.

Limestone, light buff, very fine grained, dolomitic, wavy bedded, mostly thin bedded and slabby.

Limestone, blue-gray to brownish-gray, medium to coarse grained, thin dark wavy laminae at top, locally brecciated; dolomite in lower part. cavities numerous with crystals of pyrite, calcite, and quartz.

Figure 11. Stop 1. Collinson Stone Company quarry stratigraphic section. NW Sec. 24, T. 17 N., R. 2W., Rock Island County, Illinois. From 31st Tri-State guidebook, Edmund and Anderson, 1967. 
Stop 2: Borrow pit east side of US 67.

SW NE SW Sec. 14, T. 17 N., R. 2 W., Milan 7.5' Quadrangle.

Devonian, Pennsylvanian, and Pleistocene strata are exposed in this locality.

The borrow pit exposes strata of Pennsylvanian age that are older than those seen at Stop 1. Above a gray underclay in the background is a 20 to $26 \mathrm{~cm}$ coal bed that is one of the oldest coals known in this part of the state. A gray silty shale lies above the coal. The shale is either locally nearly cut out by a sandstone channel that crosses the area or is replaced by a sandstone facies to the south (see Fig. 12). The large covered area near the center of the exposure obscures an important part of the section. The southern half of the east wall of the pit and the floor of the pit reveal Pennsylvanian strata dipping to the north and truncated to an even, nearly horizontal surface upon which Illinoian till was deposited. The till is overlain by Wisconsinan silts and thick loess. Along the southern part of the exposure, a Pleistocene channel was cut through Illinoian till to the bedrock surface and was later filled with Wisconsinan silts. Beneath this channel, bedrock strata have been considerably disturbed. Although a slight possibility exists that the Pleistocene channel had something to do with the disturbance, the location of the two features is coincidental.*

The Devonian-Pennsylvanian unconformity is exposed at several points along the north side of the Rock River for nearly $1 \mathrm{~km}$ east of Stop 2 (Section 14, T. 17 N., R. 2 W.). In addition to the exposure at this point, a second good exposure of basal Pennsylvanian sediments now exists on the bluff below the lodge in Black Hawk State Park (Stop 3, Fig. 13).

Although the Pennsylvanian-Devonian contact is approximately at river level, small knobs or "hills" of Devonian limestone are exposed in cross section along the Rock River. One of these is shown in Figure 5 and can be seen from Vandruff Island. It can be reached (though not

*Modified from the I.S.G.S. Milan Guidebook, 1974. easily) from Black Hawk State Park. The largest hill is exposed at Stop 2. The easternmost "hill" is approximately $3 \mathrm{~m}$ high and slightly irregular in form. The upper portion of the limestone is iron stained, with a sideridic top. Because the "hill" is essentially exposed only in cross section, the north-south extent is unknown.

The "hill" is overlain by $14 \mathrm{~m}$ of shale with some thin sandstone beds. Above the shale is a thick, cross-bedded sandstone. Both the shale and sandstone are unfossiliferous at this point.

About $100 \mathrm{~m}$ to the west is possibly another limestone "hill." This "hill" appears from the distance to be lower than the previously described one because the upper portion is weathered to a thin-bedded state resembling shale and thin-bedded sandstone. Less iron appears to be present here than at the eastern "hill." This second "hill" is also overlain by shale; but weathering, slumping, and vegetation obscure details of the section.

The top of the westernmost hill, $100 \mathrm{~m}$ east of US 67 (Stop 2), is approximately $10 \mathrm{~m}$ above the Rock River. It is heavily iron stained and in part replaced by iron. Because excavation has only exposed the top of this hill, its extent is not known.

Stop 3: (Lunch) Black Hawk State Park.

NE NW SE Sec. 14, T. 17 N., R. 2 W., Milan 7.5' Quadrangle.

Devonian and Pennsylvanian strata are exposed along the Rock River below and to the east of Watch Tower Inn.

(The following discussion is taken from the 31st Tri-State Geological Guidebook: The Mississippi River Arch, by R.W. Edmund and R.C. Anderson, Augustana College, 1967).

Black Hawk State Park preserves the most scenic portion of the lands once occupied by Saukenuk, the largest Indian village in the Upper Mississippi Valley. It was here that Chief Black Hawk and his band of Sauk and Fox came in conflict with the territorial claims of the white man in the years 

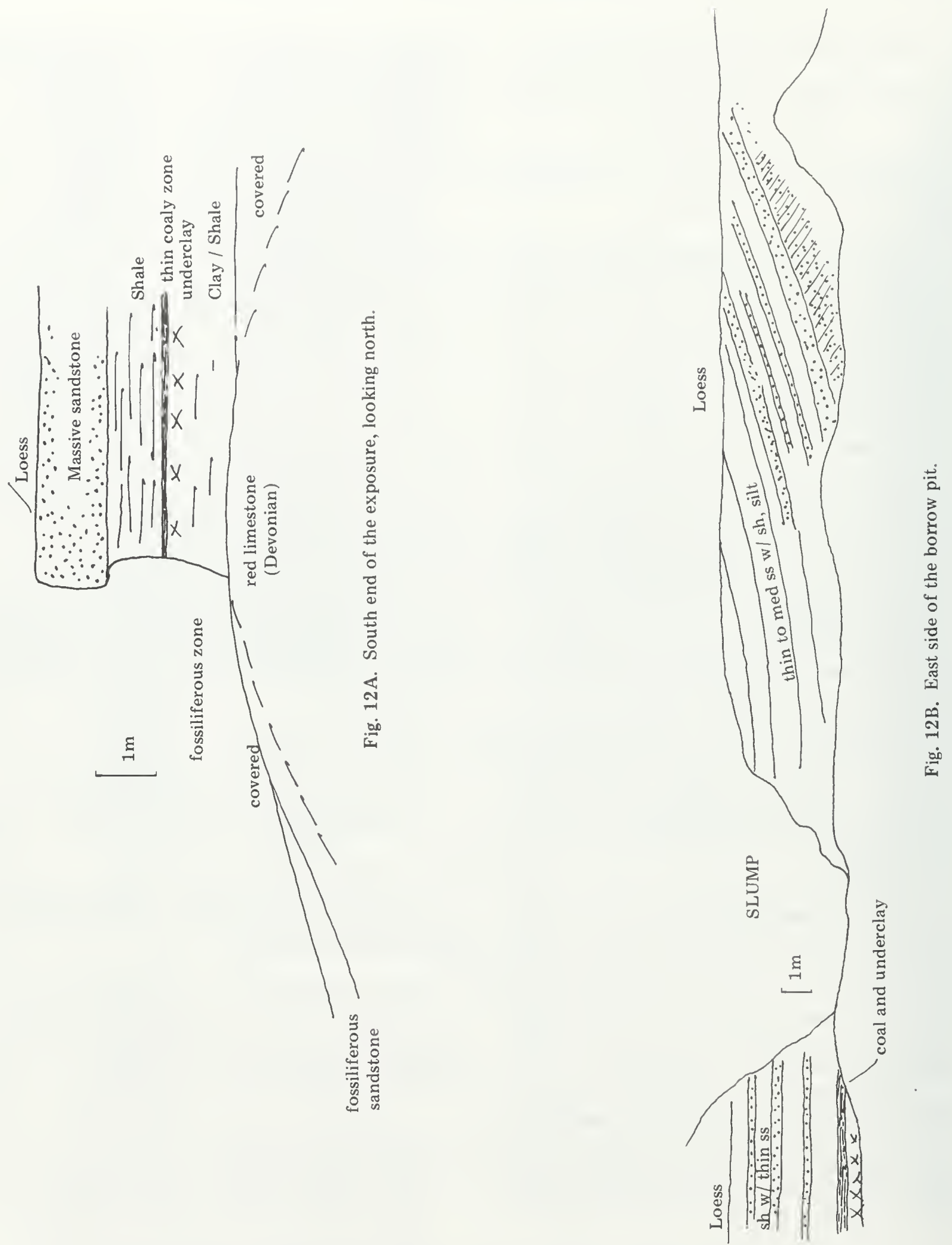

Fig. 12. Stop 2. Borrow pit, east side of U.S. 67. SW NE SW Sec. 14,

T. 17 N., R. 2 W., Milan quadrangle, Rock Island County, Illinois. 


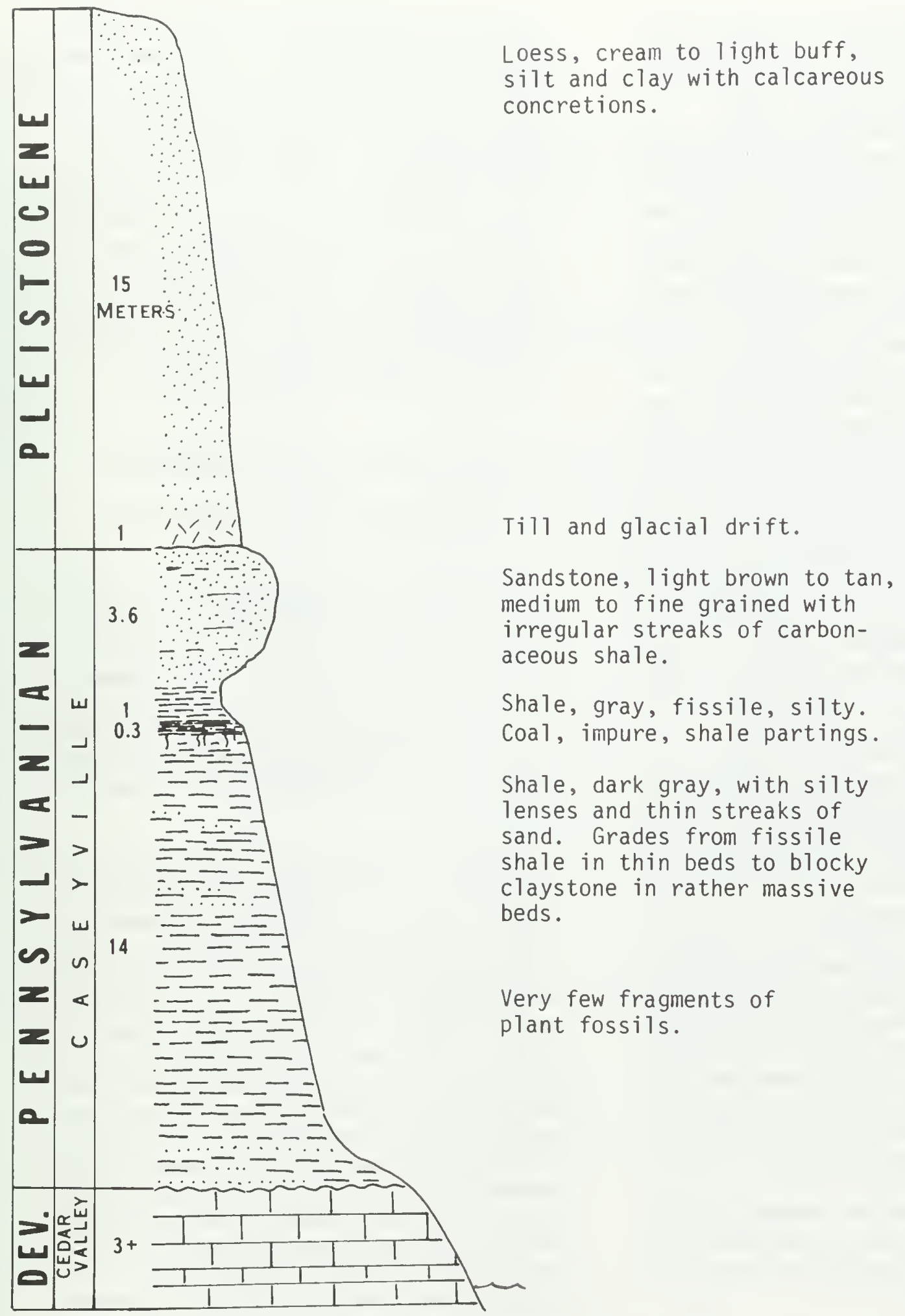

Figure 13. Stop 3. Stratigraphic section at Black Hawk State Park, Rock Island, Illinois. 
preceding the Black Hawk War of 1832. The area is rich in Indian lore, and some of it can be savored in the Black Hawk Museum on the "Watch Tower."

From the Watch Tower, a high promontory on the north bluffs of the Rock River, many of the features of the landscape in the Rock Island area can be seen. This area is characterized by flat upland prairies greatly dissected along the major streams and by broad valleys bounded by steep bluffs and occupied by sizable streams such as the Rock River.

Chief Black Hawk is reported to have said, "At the Watch Tower, which was frequently visited by me alone I could sit and smoke my pipe and look with wonder and pleasure at the grand scenes that were presented by the sun's rays, even across the mighty water." The quarry on Vandruff's Island makes it impossible for us to view this scene with the same serenity as did Black Hawk, but it has provided some very fine exposures of the Devonian Cedar Valley limestone (and fossil-bearing basal Pennsylvanian, ed.). This will be our first stop upon leaving the park.

Within the confines of Black Hawk State Park the fossiliferous Cedar Valley limestone, Devonian, crops out along the north bank of the Rock River, exposing approximately ten feet of section above water level. The Devonian beds here are overlain by sandy carbonaceous shale and gray shale totaling approximately 40 feet of strata, Pennsylvanian in age. Fragments of plant fossils have been observed directly above the Devonian in fine silty sandstones and dark gray shales. The Pennsylvanian shales are overlain by about 50 feet of Pleistocene loess (Fig. 13).

The Pennsylvanian rocks at Black Hawk State Park are representative of the exposures found on the south side of Rock Island and Moline, adjacent to the Rock River.

Dr. Russel Peppers, paleobotanist at the Illinois State Geological Survey, has examined the spore flora in the coal in this section and determined that the coal is a unit in the Caseyville Formation of the McCormick Group, being older than the Reynoldsburg Coal Member and younger than the Gentry Coal Member. This particular coal has a number of spores not found in other Illinois coals. It seems likely that this coal is of limited extent and probably was deposited in a small, discontinous basin, as along an upper delta plain or abandoned stream channel. The overlying Rock Island (No. 1) Coal is likewise discontinuous and is thought to have been deposited in an estuary (Moody, unpublished thesis 1959; Wanless, 1975).

\section{Stop 4. Allied Stone Company Quarry.}

NW SW SE Sec. 14, T. 17 N., R. 2 W., Milan 7.5' Quadrangle.

Devonian, Pennsylvanian, and Pleistocene strata are exposed in this quarry (Fig. 14). This stop affords a better opportunity to study the lower part of the Wapsipinicon Limestone (Middle Devonian) than Stop 1. As noted previously, the Wapsipinicon contains only scattered fossils. The Solon Limestone Member is the only portion of the overlying Cedar Valley Limestone present here.

Here the Allied Stone Company is quarrying Cedar Valley and Wapsipinicon limestones of Middle Devonian age (Fig. 14) and crushing the stone for road and general construction stone. As we enter we will pass the field office, scales for weighing trucks loaded with crushed stone, piles of crushed stone of various sizes, the crushing plant, and maintenance shops. The quarry itself is nearly $1.6 \mathrm{~km}$ long, $0.5 \mathrm{~km}$ wide, and up to to $12 \mathrm{~m}$ deep. Because this is an active quarry, and the plant fossils occur within the overburden, locations of fossil-bearing strata change from year to year. Over large areas of the quarry the Devonian limestone was immediately overlain by outwash as a result of erosion and deposition during the Pleistocene. Few occurrences of Pennsylvanian strata can be observed.

Probably the most striking feature of this quarry is the presence of a number of channels and caves that developed in Devonian strata. 


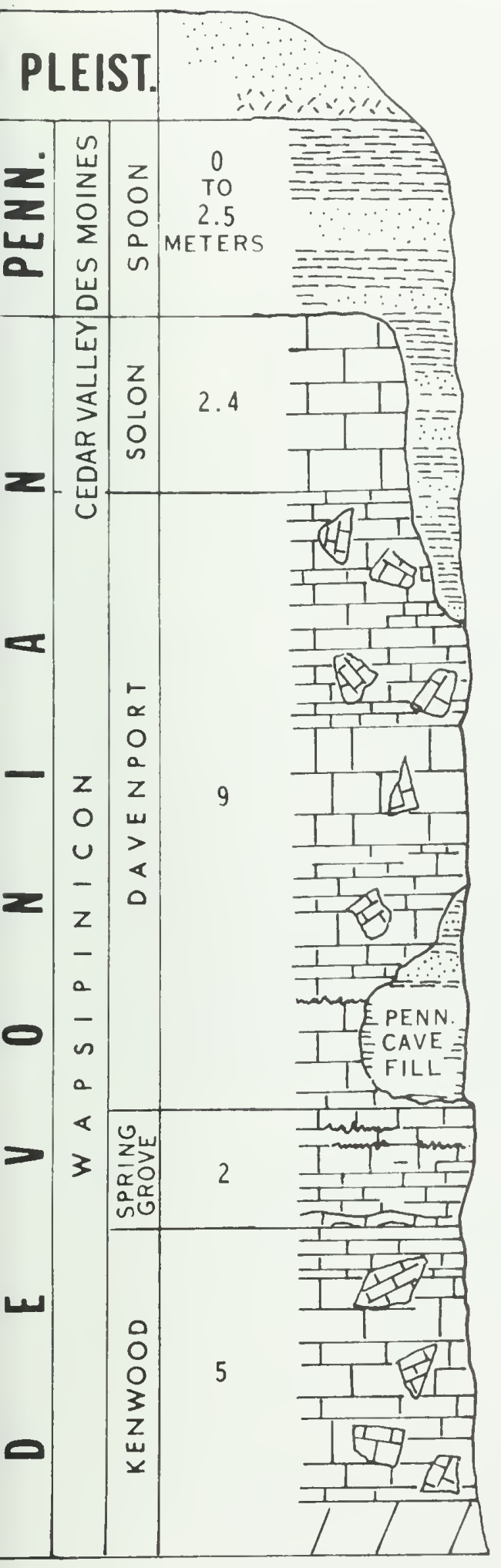

Loess and very thin glacial drift.

Shale, black to dark gray, fissile to blocky with interbedded thin sandstones. Grades down to greenish gray sandy shales and light colored pyritic sandstones.

Limestone, buff, fine to medium grained, numerous brachiopods.

Limestone, very light gray, sublithographic to 1 ithographic, very brecciated, green clay and shale streaks, graded downward to greenish gray and light brownish gray limestone, hard arld brittle, numerous wavy bands and irregular thin beds.

Cave fillings common with fine to medium angular sand interbedded with greenish clay and shale. Fragments of plants and much pyrite is common.

Limestone, very light gray to very light buff, dolomitic, lithographic to sublithographic, styolitic, weathers to thin slabs, some brecciation.

Limestone, brownish to bluish gray and dark colored, fine to coarsely crystalline with thin dark shale laminae, brecciated with shale and limestone matrix.

Dolomite, brownish-gray, fine grained.

Figure 14. Stop 4. Allied Stone Company quarry, stratigraphic section. SE $1 / 4$, Sec. 14, T. 17 N., R. 2 W, Rock Island County, Illinois. 
These features must have formed after the end of Mississippian deposition because they contain no sediments of Mississippian age. On the other hand, they must have existed before widespread Pennsylvanian sedimentation began in this area, for the sediments filling them are among some of the oldest-known Pennsylvanian strata in the state. These Pennsylvanian rocks occur stratigraphically lower than the Pennsylvanian layers at a neighboring borrow pit (Stop 2) and across the Rock River at Black Hawk State Park.

The solution features strongly suggest that this area was topographically high-part of the Mississippi River Arch - when they were formed. Four conditions contribute to the development of such large numbers of sinkholes: First, soluble rock, preferably limestone, must occur at or near the surface and should be flat-lying, or nearly so. Second, and one of the most important factors, the limestone should be dense, abundantly jointed, and preferably thinly bedded. The limestone should not be porous; if it is, rainwater will be absorbed, moving through the whole body of the rock rather than being concentrated along joints and bedding planes. Third, major valleys must be entrenched below the uplands, serving as outlets toward which the ground water can move in the subsurface. Fourth, there must be ample rainfall.

Sinkholes form in two ways. Collapse sinks, known as ponors, are caused by the collapse of the roofs of caves that lie near the surface. Caves were initially formed above the zone of saturation by ground water percolating downward (such water is called vadose water). Roof collapse followed uplift of the area and subsequent entrenchment of major drainage channels.
Collapse sinks are generally deep and steep walled. A second type of sinkhole is called a doline, in which solution takes place along joints beneath the soil mantle so that the surface is gradually lowered without collapsing the rock mass. They do not require the presence of large subterranean cavities, most of them being shallow, saucer-shaped depressions. Their depth is controlled by the depth of the water table at the time of their formation. Both types of sinks are generally present in a sinkhole area, but dolines generally are more common.*

The basal Pennsylvanian deposits in this quarry have been the major source of plant fossils representing Early Pennsylvanian "upland" floras in Illinois. Although now largely removed by quarrying operations, some fossil-bearing channel deposits can be seen and plant fossils can be collected.

The plant fossils occur in the shale and mudstone which fill elongate depressions (channels) eroded in the Middle Devonian Cedar Valley Limestone. The channels are 4 to $6 \mathrm{~m}$ deep and 8 to $20 \mathrm{~m}$ wide. One channel can be seen in cross section at the top of the north wall at about mid-quarry. As of late 1978 they can best be seen at the west end of the quarry where several channels are visible in both cross section and horizontally (see diagram, Fig. 8). During the autumn of 1978 the best plant fossil collecting was in the channel nearest the large gravel pile (arrow on Fig. 7). The only Pennsylvanian animal fossils yet discovered here, a scorpion (Leary, in press) and a single fish scale, were found at this site in October, 1977.

\footnotetext{
*Modified from the I.S.G.S. Milan Guidebook, 1974.
} 
The following section on Mississippian deposition is taken from Illinois State Geological Survey Report of Investigations 216: Classification of Genevievian and Chesterian ... Rocks of Illinois (1963) by D.H. Swann, pp. 11-16. The section on Pennsylvanian deposition is taken from Illinois State Geological Survey publications.

\section{MISSISSIPPIAN DEPOSITION}

During the Mississippian Period, the Illinois Basin was a slowly subsiding region with a vague north-south structural axis. It was flanked by structurally neutral regions to the east and west, corresponding to the present Cincinnati and Ozark arches. These neighboring elements contributed insignificant amounts of sediment to the basin. Instead, the basin was filled by locally precipitated carbonate and by mud and sand eroded from highland areas far to the northeast in the eastern part of the Canadian Shield and perhaps the northeastward extension of the Appalachians. This sediment was brought to the Illinois region by a major river system, which it will be convenient to call the Michigan River (Fig. 15) because it crossed the present state of Michigan from north to south or northeast to southwest ....

The Michigan River delivered much sediment to the Illinois region during early Mississippian time. However, an advance of the sea midway in the Mississippian Period prevented sand and mud from reaching the area during deposition of the St. Louis Limestone. Genevievian time began with the lowering of sea level and the alternating deposition of shallow-water carbonate and clastic units in a pattern that persisted throughout the rest of the Mississippian. About a fourth of the fill of the basin during the late Mississippian was carbonate, another fourth was sand, and the remainder was mud carried down by the Michigan River.

Thickness, facies, and crossbedding .... indicate the existence of a regional slope to the southwest, perpendicular to the prevailing north $65^{\circ}$ west trend of the shorelines. The Illinois Basin, although developing structurally during this time, was not an embayment of the interior sea. Indeed, the mouth of the Michigan River generally extended out into the sea as a bird-foot delta, and the shoreline across the basin area may have been convex more often than concave.

. The shoreline was not static. Its position oscillated through a range of perhaps 600 to 1,000 or more miles $(970-1,600 \mathrm{~km})$. At times it was so far south that land conditions existed throughout the present area of the Illinois Basin. At other times it was so far north that there is no suggestion of near-shore environment in the sediments still preserved. This migration of the shoreline and of the accompanying sedimentation belts determined the composition and position of Genevievian and Chesterian rock bodies.

Lateral shifts in the course of the Michigan River also influenced the placement of the rock bodies. At times the river brought its load of sediment to the eastern edge of the basin, at times to the center, and at times to the western edge. This lateral shifting occurred within a range of about 200 miles $(320 \mathrm{~km})$. The Cincinnati and Ozark areas did not themselves provide sediments, but, rather, the Michigan River tended to avoid those relatively positive areas in favor of the down-warped basin axis.

Sedimentation belts during this time were not symmetrical with respect to the mouth of the Michigan River. They were distorted by the position of the river relative to the Ozark and Cincinnati shoal areas, but of greater importance was sea current or drift to the northwest. This carried off most of the mud contributed by the river, narrowing the shale belt east of the river mouth and broadening it west of the mouth. Facies and isopach maps of individual units show several times as much shale west of the locus of sand deposition as east of it. The facies maps of the entire Chesterian... show maximum sandstone deposition in a northeastsouthwest belt that bisects the basin. The total thickness of limestone is greatest along the southern border of the basin and is relatively constant along that entire border. The proportion of limestone, however, is much higher at the eastern end than along the rest of the southern border, because little mud was carried southeastward against the prevailing sea current. Instead, the mud was carried to the northwest and the highest proportion of shale is found in the northwestern part of the basin. 


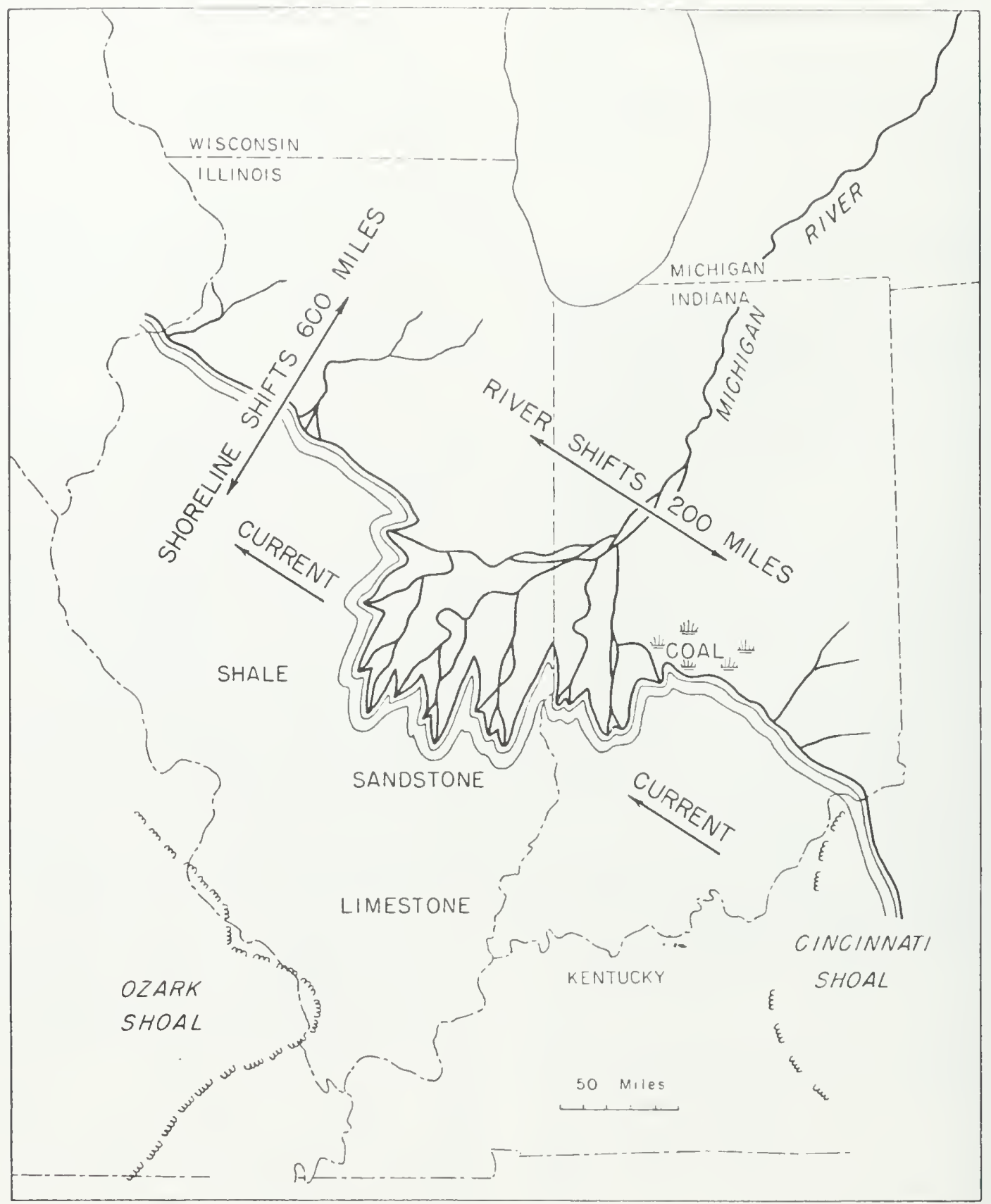

Figure 15. Paleogeography at an intermediate stage during Chesterian (Mississippian) sedimentation. From Swann, 1963. 
Genevievian and Chesterian seas generally extended from the Illinois Basin eastward across the Cincinnati Shoal area and the Appalachian Basin. Little terrigenous sediment reached the Cincinnati Shoal area from either the west or the east, and the section consists of thin limestone units representing all or most of the major cycles. The proportion of inorganically precipitated limestone is relatively high and the waters over the shoal area were commonly hypersaline.... Erosion of the shoal area at times is indicated by the presence of conodonts erorded from the St. Louis Limestone and redeposited in the lower part of the Gasper Limestone at the southeast corner of the Illinois Basin ....

The shoal area included regions somewhat east of the present Cincinnati axis and extended from Ohio, and probably southeastern Indiana, through central and east-central Kentucky and Tennessee into Alabama....

Toward the west, the seaway was commonly continuous between the Illinois Basin and Central Iowa, although only the record of Genevievian and earliest Chesterian is still preserved. The seas generally extended from the Illinois and Black Warrior regions into the Arkansas Valley region, and the presence of Chesterian outliers high in the Ozarks indicates that at times the Ozark area was covered. Although the sea was continuous into the Ouachita region, detailed correlation of the Illinois sediments with the geosynclinal deposits of this area is difficult.

\section{PENNSylvanian DePosition}

At the close of the Mississippian Period, about 310 million years ago, the Mississippian sea withdrew from the Midcontinent region. A long interval of erosion took place early in Pennsylvanian time and removed hundreds of feet of the pre-Pennsylvanian strata, completely stripping them away and cutting into older rocks over large areas of the Midwest. An ancient river system cut deep channels into the bedrock surface. Erosion was interrupted by the invasion of the Morrowan (early Pennsylvanian) sea.

Depositional conditions in the Illinois Basin during the Pennsylvanian Period were somewhat similar to those that existed during Chesterian (late Mississippian) time. A river system flowed southwestward across a swampy lowland, carrying mud and sand from highlands in the northeast. A great delta was built out into the shallow sea. As the lowland stood only a few feet above sea level, only slight changes in relative sea level caused great shifts in the position of the shoreline.

Throughout Pennsylvanian time the Illinois Basin continued to subside while the delta front shifted owing to worldwide sea level changes, intermittent subsidence of the basin, and variations in the amounts of sediment carried seaward from the land. These alternations between marine and nonmarine conditions were more frequent than those during pre-Pennsylvanian time, and they produced striking lithologic variations in the Pennsylvanian rocks.

Conditions at various places on the shallow sea floor favored the deposition of sandstone, limestone, or shale. Sandstone was deposited near the mouths of distributary channels. These sands were reworked by waves and spread as thin sheets near the shore. The shales were deposited in quiet-water areas-in delta bays between distributaries, in lagoons behind barrier bars, and in deeper water beyond the near-shore zone of sand deposition. Most sediments now recognized as limestones, which are formed from the accumulation of limey parts of plants and animals, were laid down in areas where only minor amounts of sand and mud were being deposited. Therefore, the areas of sandstone, shale, and limestone deposition continually changed as the position of the shoreline changed and as the delta distributaries extended seaward or shifted their positions laterally along the shore.

Nonmarine sandstones, shales, and limestones were deposited on the deltaic lowland bordering the sea. The nonmarine sandstones were deposited in distributary channels, in river channels, and on the broad floodplains of the rivers. Some sand bodies, 100 or more feet thick $(30 \mathrm{~m})$, were deposited in channels that cut through many of the underlying rock units. The shales were deposited mainly on floodplains. Freshwater limestones and some shales were deposited locally in freshwater lakes and swamps. The coals were formed by the accumulation of plant material, usually where it grew, beneath 
the quiet waters of extensive swamps that prevailed for long intervals on the emergent delta lowland. Lush forest vegetation, which thrived in the warm, moist Pennsylvanian climate, covered the region. The origin of the underclays beneath the coals is not precisely known, but they were probably deposited in the swamps as slackwater muds before the formation of the coals. Many underclays contain plant roots and rootlets that appear to be in their original places. The formation of coal marked the end of the nonmarine portion of the depositional cycle, for resubmergence of the borderlands by the sea interrupted nonmarine deposition, and marine sediments were then laid down over the coal. 
Andrews, H.N.

1875 Description of fossil plants (Rushville, Ohio). Rept. of Geol. Surv. of Ohio. 2(2), p. 413-426.

Arber, E.A.

1904 Culm Measures of northwest Devon and the age of the coal beds. Phil. Trans. Royal Soc. London, B. 197, p. 307.

Arnold, C.A.

1934 A preliminary study of the fossil flora of the Michigan Basin. Museum of Paleontology, University of Michigan, 4(11), p. 177-204.

Bell, W.A.

1940 The Pictou coalfield, Nova Scotia. Geol. Surv. Canada, Mem. 225, 160 p.

Boureau, Edward (Editor)

1964 Tome 3: Sphenophyta, Noeggerathiophyta. Traite de Paleobotonique, Paris.

Bristol, H.M. and R.H. Howard

1971 Paleogeologic map of the sub-Pennsylvanian Chesterian (Upper Mississippian) surface in the Illinois Basin. Ill. State Geol. Surv. Cir. 458,16 p.

Canwright, J.E.

1959 Fossil Plants of Indiana. Indiana Geol. Surv. Report of Progress, 14, 45 p.

Cross, A.T.

1962 The Rushville (Ohio) Pennsylvanian Flora (abs.). Amer. Jour. Botany 49(6), Pt. 2, p. 669 .

Dawson, J.W.

1871 The fossil plants of the Devonian and Upper Silurian formations of Canada. Canada Geol. Surv., 92 p., 20 pl.

Edmund, R.W., and R.C. Anderson

1967 The Mississippi River Arch, 31st Annual TriState field conference, Augustana College, Rock Island, Ill., 64 p.

Feistmantel, K.

1879 Eine naue Pflanzengattung aus bohmischen Steinkohlen-schichten. Sitzber. Ges. Wiss., p. 298-303.

Florin, Rudolf

1933 Zur Kenntnis der palaozoischen Pflanzengattung Lesleya Lesquereux und Megalop- teris Dawson. Arkiv for Botanik, (K. Svenska Vetensk. Akad.), 25A(19), 23 p.

Havlena, V.

1961 Die flonznahe und flozfremde Flora des oberschlesischen Namurs A und B. Palaeon. tographica Abt. B, Vol. 108, p. 22-38.

1970 Ecology and mode of deposition of the macroflora in cyclothems of the Ostrava Formation (Namurian A). Vestnik Ustredniho ustavu geologickeno, 45, p. 291-294.

1971 Die zeitgleichen Floren des Europaischen Oberkarbons und die mesophile Flora des Ostrau-Karwiner Steinkohlenreviers. Rev. Palaeobot. Palynol., 12(4), p. 245-270.

Hirmer, M.

1940 Die Karbon-Flora des Saargebietes, 3. Filicales und Vermandte, 1. Noeggerathiineae. Paleontographica, 9 , p. 3-44.

1941 Noeggerathia, neuentdeckte Formen und ihre Stellung im System der Farne, Biol. Generalis, $15(1,2)$, p. 134-171.

Horberg, C.L.

1950 Bedrock topography of Illinois. Ill. State Geol. Surv. Bull. 73, 111 p.

Leary, R.L.

1973 Lacoea, A Lower Pennsylvanian Fructification of Noeggerathialian Affinity from Brown County, Illinois. Review of Palaeobot. Palynol. 15(1), p. 43-50.

1974a Stratigraphy and floral characteristics of the basal Pennsylvanian strata in west-central Illinois. Compte Rendu, 7th International Congress of Stratigraphy and Geology of the Carboniferous, Krefeld, Germany, 1971, Vol. 3, p. 341-350.

1974b Two early Pennsylvanian floras of western Illinois. Illinois State Academy of Science Transactions, vol. 67, no. 4, p. 430-440, 1974.

1976 Early Pennsylvanian paleogeography of an upland area, western Illinois. Bulletin de la Societe belge de Geologie, vol. 84 , no. 1 , p. 19-31, 1975 (1976).

(In press) Namurian paleogeography of the western margin of the Eastern Interior (Illinois) Basin. Compte Rendu, Eighth International 
Congress on Stratigraphy and Geology of the Carboniferous, Moscow, USSR, 1975.

(In press) Labriscorpio alliedensis, gen. et sp. nov: a new Carboniferous scorpion from Rock Island County, Illinois. Jour. of Paleontology.

Leary, R.L., and H.W. Pfefferkorn

1977 An Early Pennsylvanian flora with Megalopteris and Noeggerathiales from westcentral Illinois. Ill. State Geol. Surv., Cir. $500,77 \mathrm{p}$.

Lesquereux, Leo

1880 Description of the Coal Flora of the Carboniferous Formation in Pennsylvania and throughout the U.S. Second Geol. Surv. Penn. Rept. Progress, Harrisburg. Vol. 1 \& 2 .

McGinnis, L.D., and P.C. Heigold

1974 A seismic refraction survey of the Meredosia Channel area of northwestern Illinois. Ill. State Geol. Surv. Cir. 488, 19 p.

Moody, D.M.

1959 The geology of the Rock Island (No. 1) Coal in northwestern Illinois; Rock Island, Henry, Mercer and Warren counties. Unpublished M.S. thesis, Univ. of Illinois. 38 p.

Newberry, J.S.

1873 Descriptions of fossil plants. Palaeontology, vol. I, pt. II Geological Surv. of Ohio, p. $359-385$.

Noe, A.C.

1925 Pennsylvanian Floras of Illinois. Illinois State Geol. Surv. Bull. 52, 113 p.

Peppers, R.A., and H.W. Pfefferkorn

1970 A comparison of the floras of the Colchester (No. 2) Coal of the Francis Creek Shale. In Depositional environments in parts of the Carbondale Formation, western and northern Illinois, Ill. State Geol. Surv. Guidebook series no. 8, p. 61-74.

Phillips, T.L., H.W. Pfefferkorn, and R.A. Peppers 1973 Development of paleobotany in the Illinois Basin. Ill. State Geol. Surv. Cir. 480, 86 p.

Phillips, T.L., A.B. Kunz, and D.J. Mickish

1974 Paleobotany of petrified peat (coal balls) from the Herrin (No. 6) Coal Member of the Illinois Basin. Geol. Soc. Amer., Abst. Prog., vol. 6, no. 7, p. 912.
Purkynova, Eva

1970 Die Unternamurflora des Beckens von Horni Slezsko (CSSR). (The lower Namurian flora of the Upper Silesian Basin, Czechoslovakia.) Palaontologische Abhundlunge Palaobotanik, Abt. B, 3(2), p. 129-268.

Read, C.B.

1946 A Pennsylvanian florule from the Forkston Coal in the Dutch Mountain Outlier Northeastern Penn. USGS Prof. Paper 210B, p. $17 \cdot 27$.

Reinertsen, D.L., D.J. Berggren, R.C. Anderson, and M. Killey

1974 Milan area, guide leaflet, Ill. State Geol. Surv. guide leaflet 1974-C, 1975-B, 19 p.

Remy, W., and R. Remy

1977 Die Floren des Erdaltertums. Verlag Gluckauf Gmbh. Essen. 468 p.

Searight, T.K., and W.H. Smith

1969 Strippable coal reserves of Illinois, pt. 5B-Mercer, Rock Island, Warren, and parts of Henderson and Henry counties. Ill. State Geol. Surv. Cir. 439, 22 p.

Smith, M.H.

1941 Structure contour map of the pre-Pennsylvanian surface of Illinois. Ill. State Acad. Sci. Trans. 34(2), p. 160-163.

Stockmans, F. and F.F. Mathieu

1957 La Flore Paleozoique du Bassin Houilles de Kaiping. Pub. 32 Assoc. pour L'etude de la Paleoutologie et de la Stratigraphic Houilles Bruxelles, 89 p.

Stockmans, F. and Y. Williere

1962 Heninia, Discinites et Tongshania. Inst. R. Sci. Nat. Belg., 38(3), p. 1-8.

Stopes, M.C.

1914 The "Fern Ledges" Carboniferous flora of St. John, New Brunswick, Geol. Survey Canada Mem. 41, 167 p.

Sustra, V.

1928 Stratigraphie des Ostrau-Karviner Steinkohlenreviers im lichte der Palaontologie. Der Kohlenbergbau des Ostrau-Karviner Steinkohlenreviers, I, p. 385-484, 75 pl. Ostrava.

Swann, D.H.

1963 Classification of Genevievian and Chesterian 
(Late Mississippian) rocks of Illinois. Ill. State Geol. Surv. Rept. Investigations 216, 91 p.

Tenchov, Y.G.

1976 Composition peculiarities of the Carboniferous flora of the Svoge Basin, west Bulgaria. Geologica Balcaniea, vol. 6, no. 1, p. 3-11.

Wanless, H.R.

1975 Distribution of Pennsylvanian coal in the United States. Paleotectonic investigations of the Pennsylvanian System in the United States, part II, p. 33-47.

White, David

1908 Report on Field Work Done in 1907. Ill. State Geol. Surv. Bull. 8, p. 268-272.

\section{ADDITIONAL REFERENCES 1985}

\section{Leary, R.L.}

1979 Early Pennsylvanian upland compression flora, Rock Island County, Illinois: 1llinois State Museum Guidebooklet Series $4,42 \mathrm{p}$.

Leary, R.L.

1980 Labriscorpio alliedensis, sen. et sp. nov: a new Carboniferous scorpion from Ruck Island County, Illinois: Journal of Paleontology, v. 54, no. 6, p. 1255-1257.

Leary, R.L.

1981 Early Pennsylvanian geology and paleo. botany of the Rock Island County, Illinois, area. Part 1: Geology: Illinois State Museum Reports of Investigation $37,88 \mathrm{p}$.

Phillips, T.L., and R.A. Peppers

1984 Changing patterns of Pennsylvanian coal. swamp vegetation and implications of climatic control on coal occurrence: International Journal of Coal Geology, v. 3, p. $205-255$
1913 Fossil flora of West Virginia. West Virginia Geol. Surv. 5(A), pt. II, p. 390-453.

1931 Climatic Implications of Penn. Flora. Papers presented at the Quarter Centennial Celebration of the ISGS. III. State Geol. Surv. Bull. 60, p. 271-281.

Wood, J.M.

1963 The Stanley Cemetery Flora (Early Pennsylvanian) of Green County, Indiana. Ind. Geol. Surv. Bull. 29, 73 p.

Worthen, A.H.

1873 Geological Survey of Illinois, Vol. 5, p. 217-234 
PLAT'ES

Plate 1

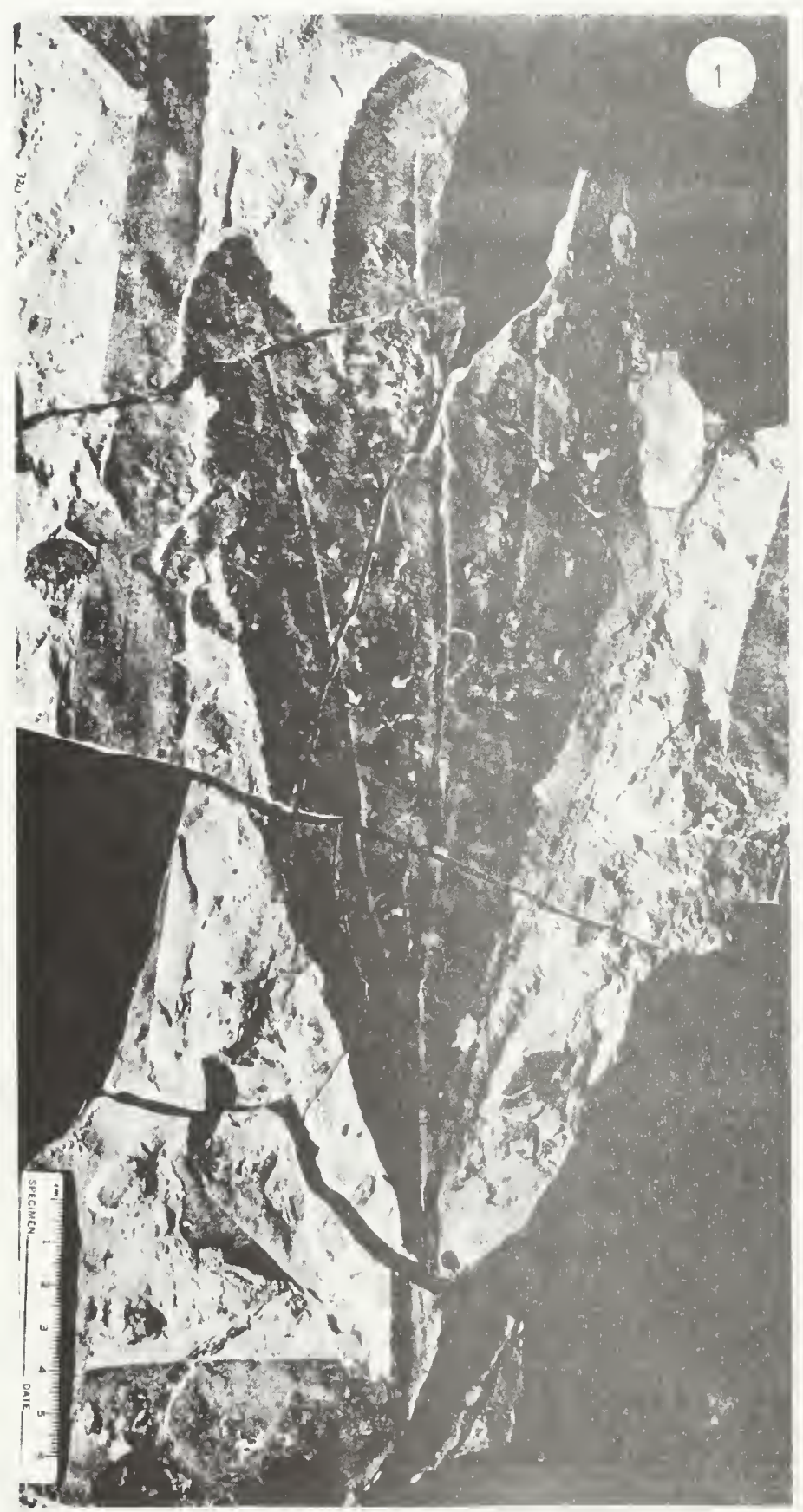

Fig. 1. Megalopteris dawsoni x $1 / 2$

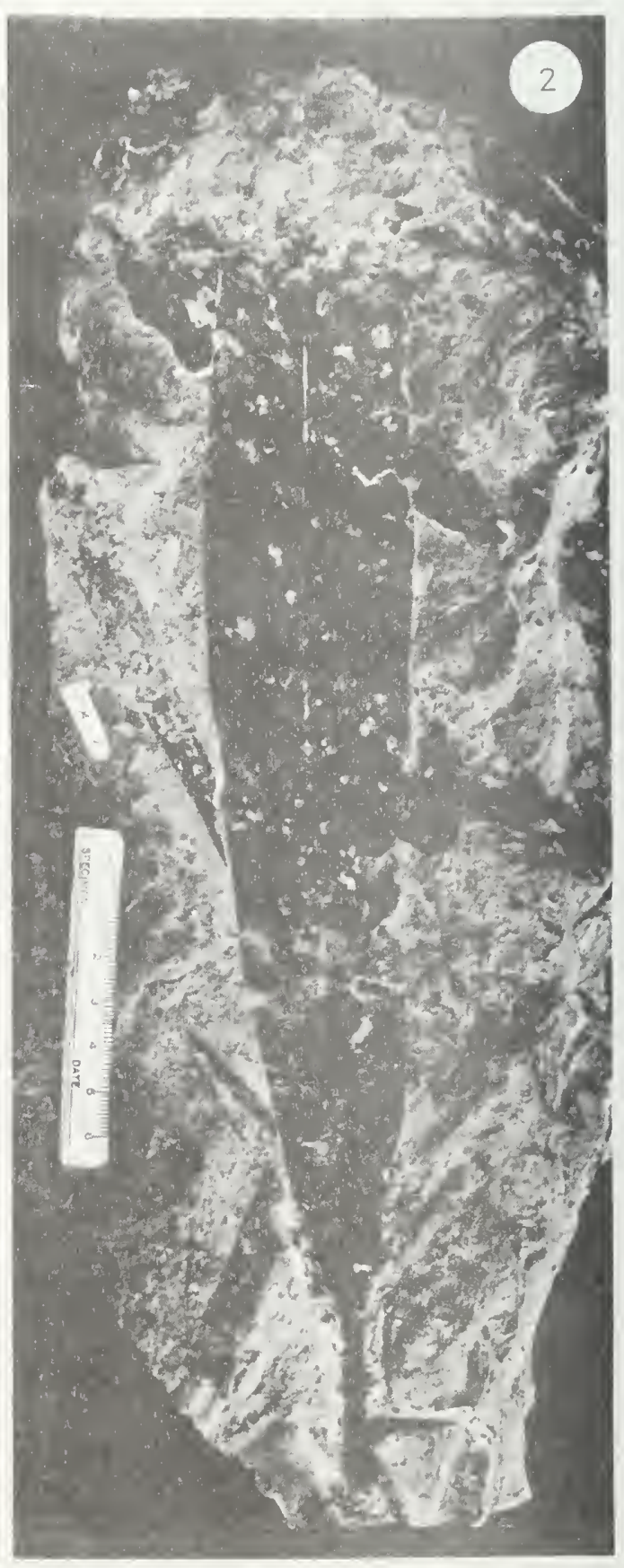

Fig. 2. Lesleya cheimarosa $\times 1 / 2$ 

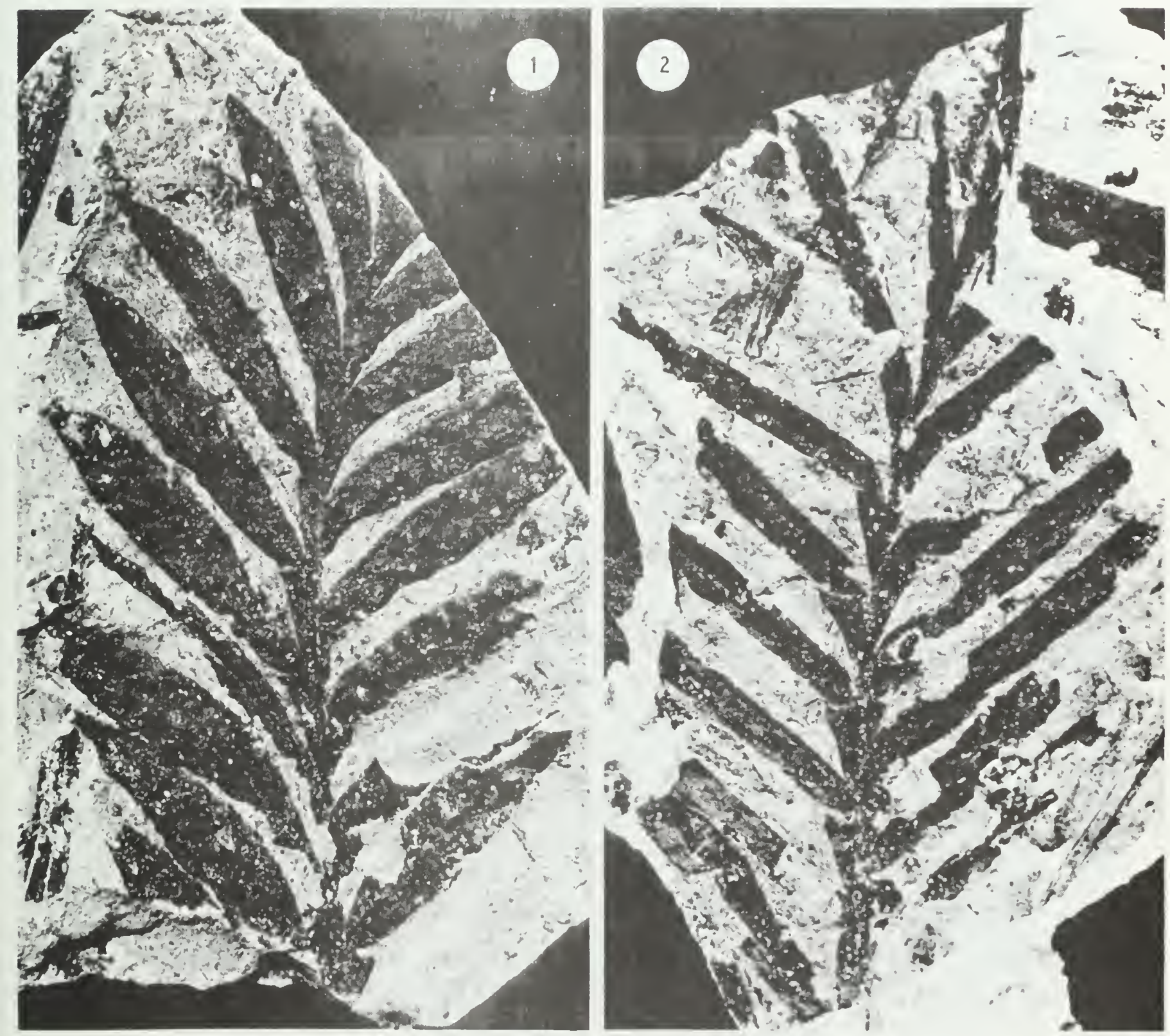
Plate 3

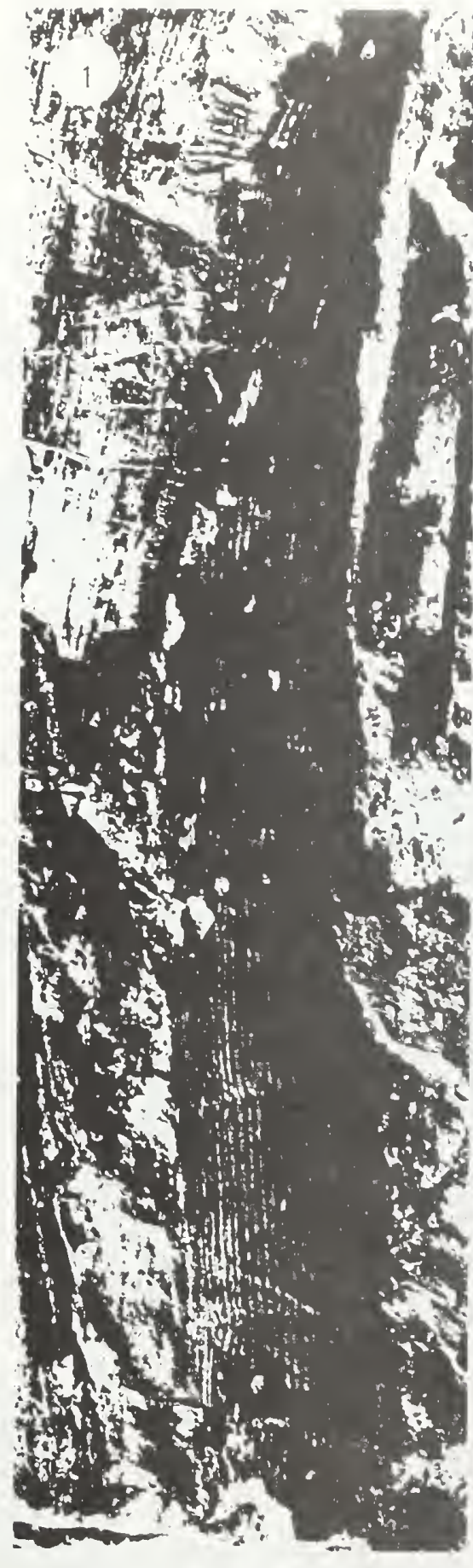

Fig. 1. Mesocalamites sp. $\mathrm{x} 1$

Fig. 2. Gulpenia sp. x 2

Fig. 3. Samaropsis newberryi $\mathrm{x} 1$

Fig. 4. Sphenophyllum tennerrimum $\mathrm{x} 1$
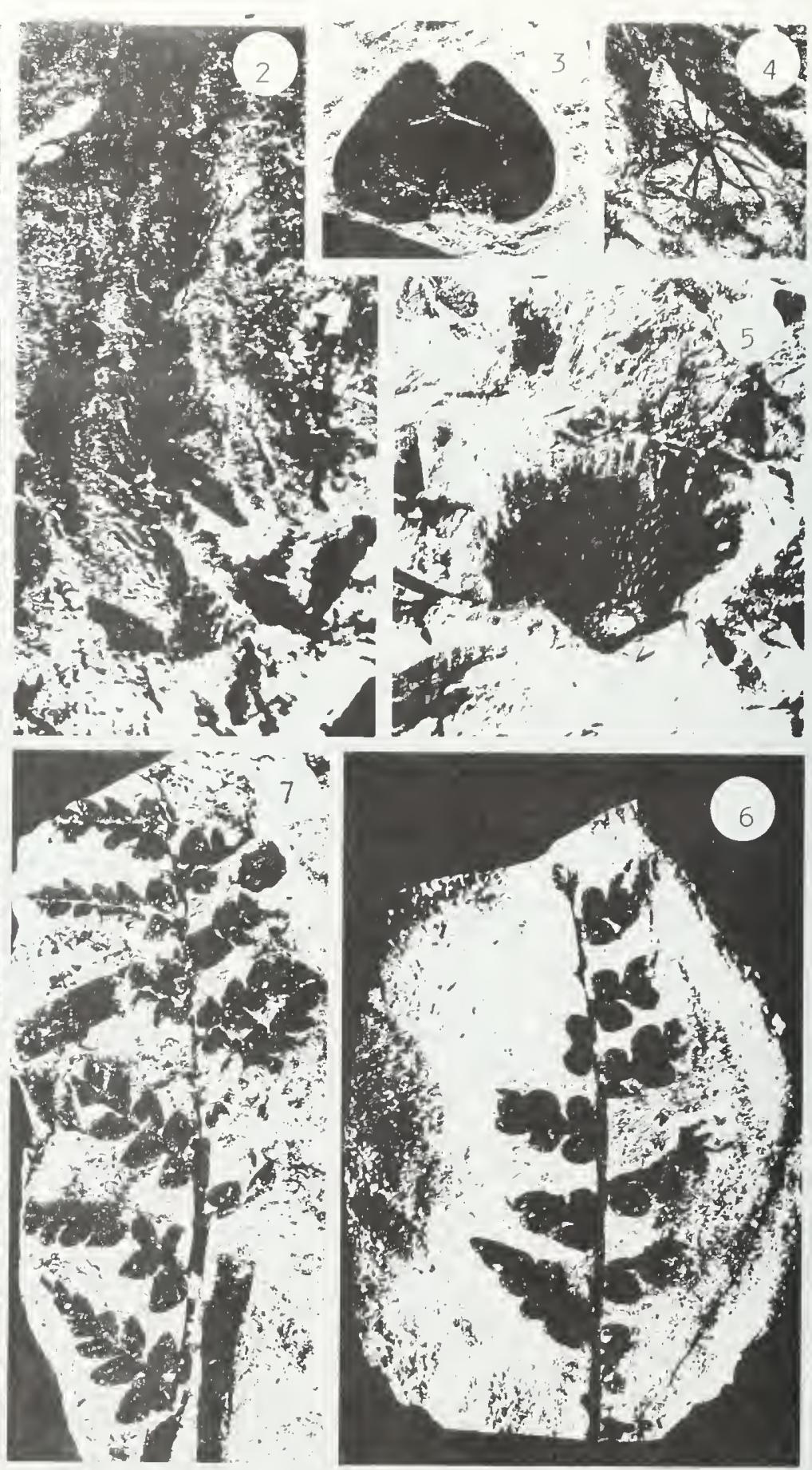

Fig. 5. Lacoea seriata $\mathrm{x} 1$

Fig. 6. Sphenopteris $\mathrm{sp} . \mathrm{x} 1$

Fig. 7. Mariopteris sp. $\mathrm{x} 1$ 


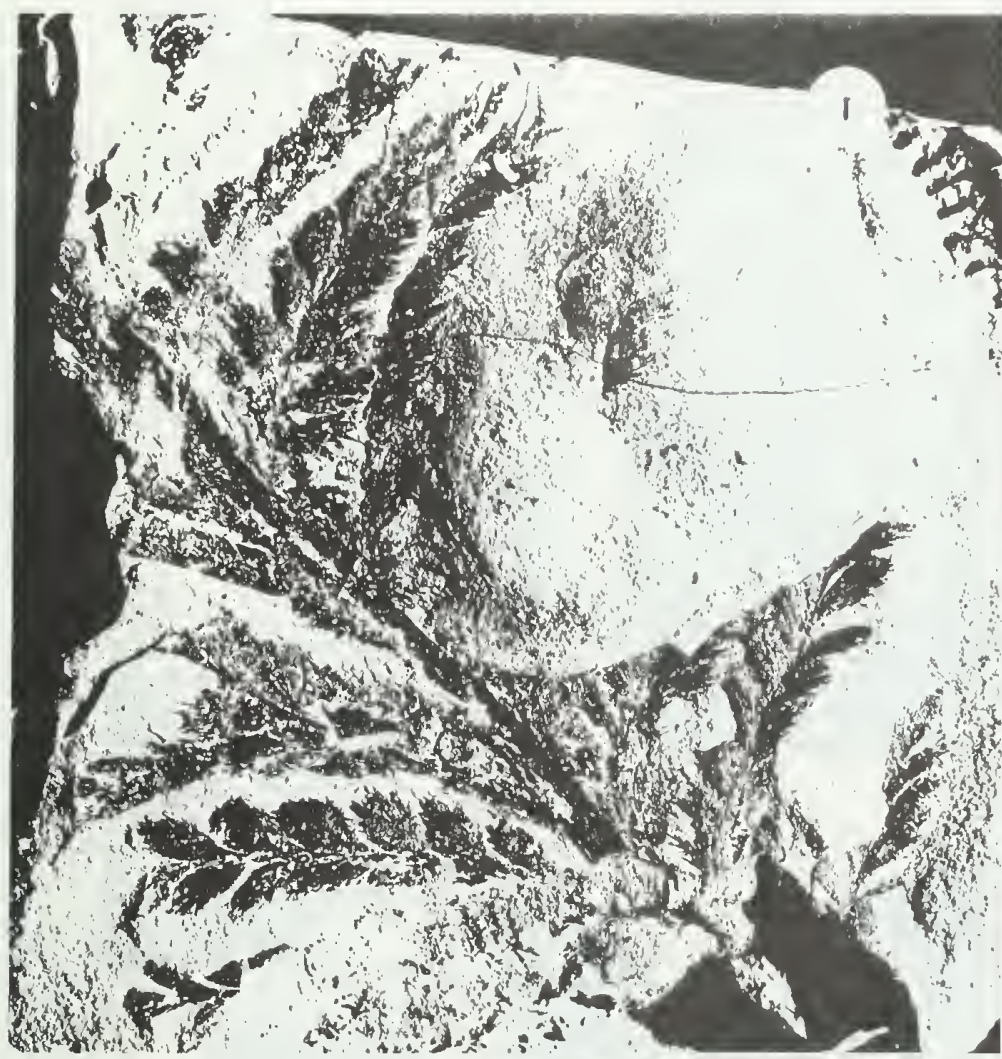

* lis con
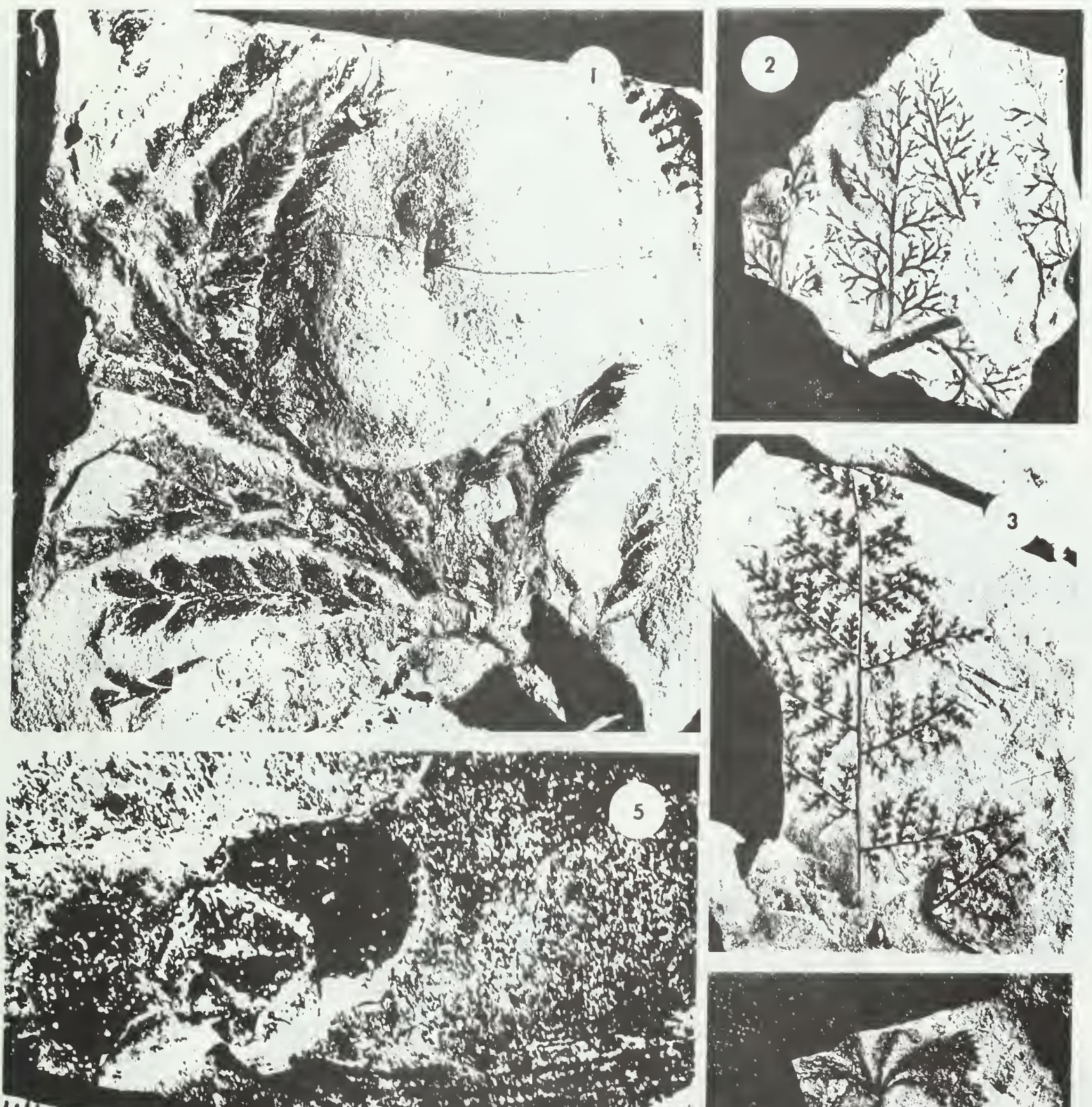

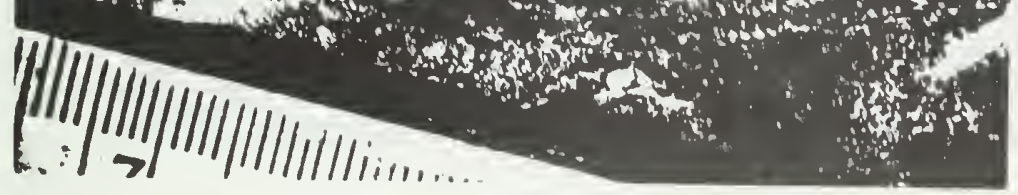
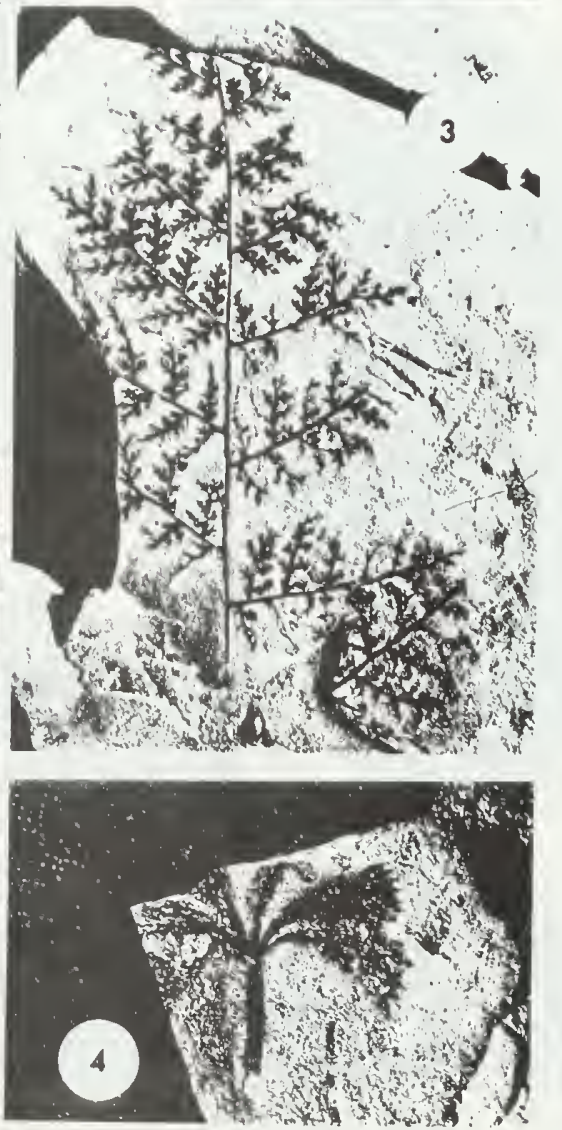

Fig. 1. Palaeopteridium reussii $\times 2$

Fig. 2. Sphenopteris sp. $\mathrm{x} 1$

Fig. 3. Sphenopteris sp. $\mathrm{x} 1$
Fig. 4. Sphenophyllum cuneifolium ? $\times 2$

Fig. 5. Samaropsis newberryi $\mathrm{x} 1$ 
Plate 5

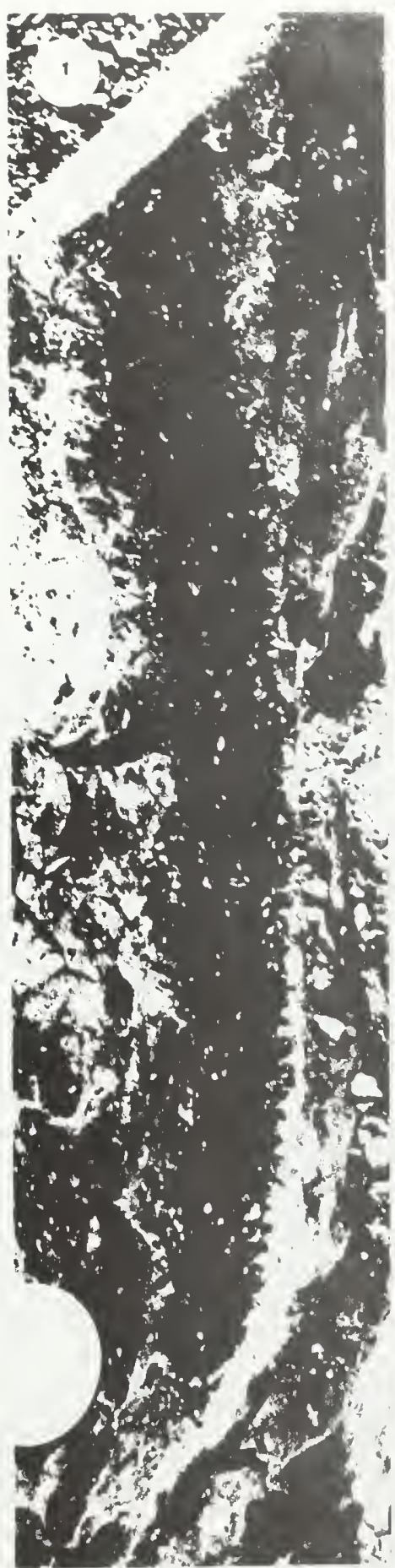

Fig. 1. Lepidostrobus sp. $\mathrm{x}^{3 / 4}$

Fig. 2. Lepidodendron sp. $\mathrm{x} 1$

Fig. 3. Lepidocarpon $\mathrm{sp} . \mathrm{x} 2$

Fig. 4. Lepidocarpon sp. x 2
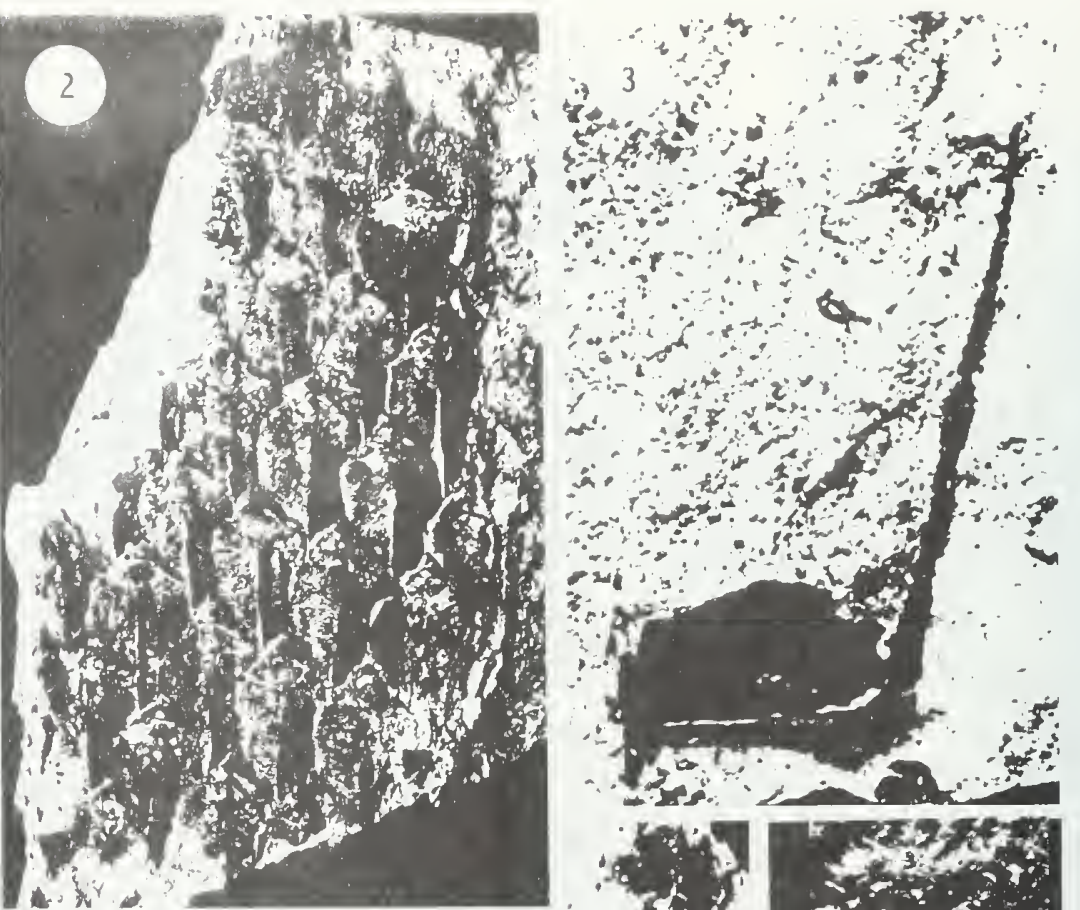
(x) 1

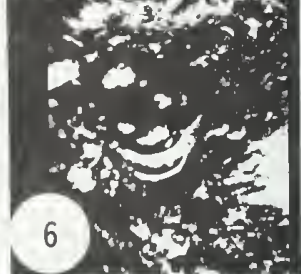

$3 x$ sis lo

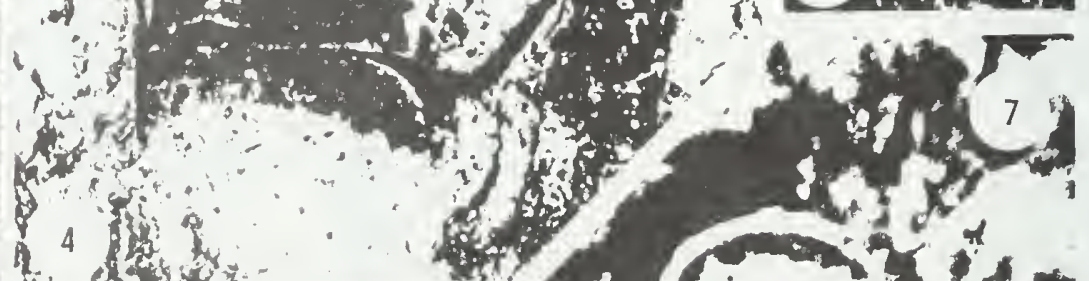

$4{ }^{4} x^{2}$
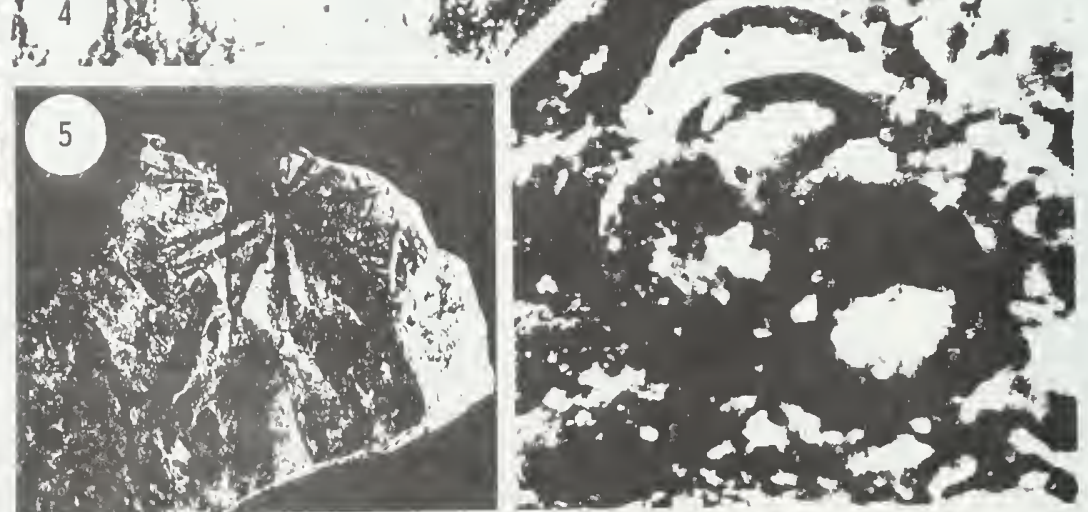

Fig. 5. Sphenophyllum sp. $\mathrm{x} 1$

Fig. 6. Triletes auritus tetrad $\times 5$

Fig. 7. Triletes auritus tetrad $\mathrm{x} 15$ 
NOTES 
LOWER PENNSYLVANIAN PLANT FOSSILS

OF WESTERN ILLINOIS
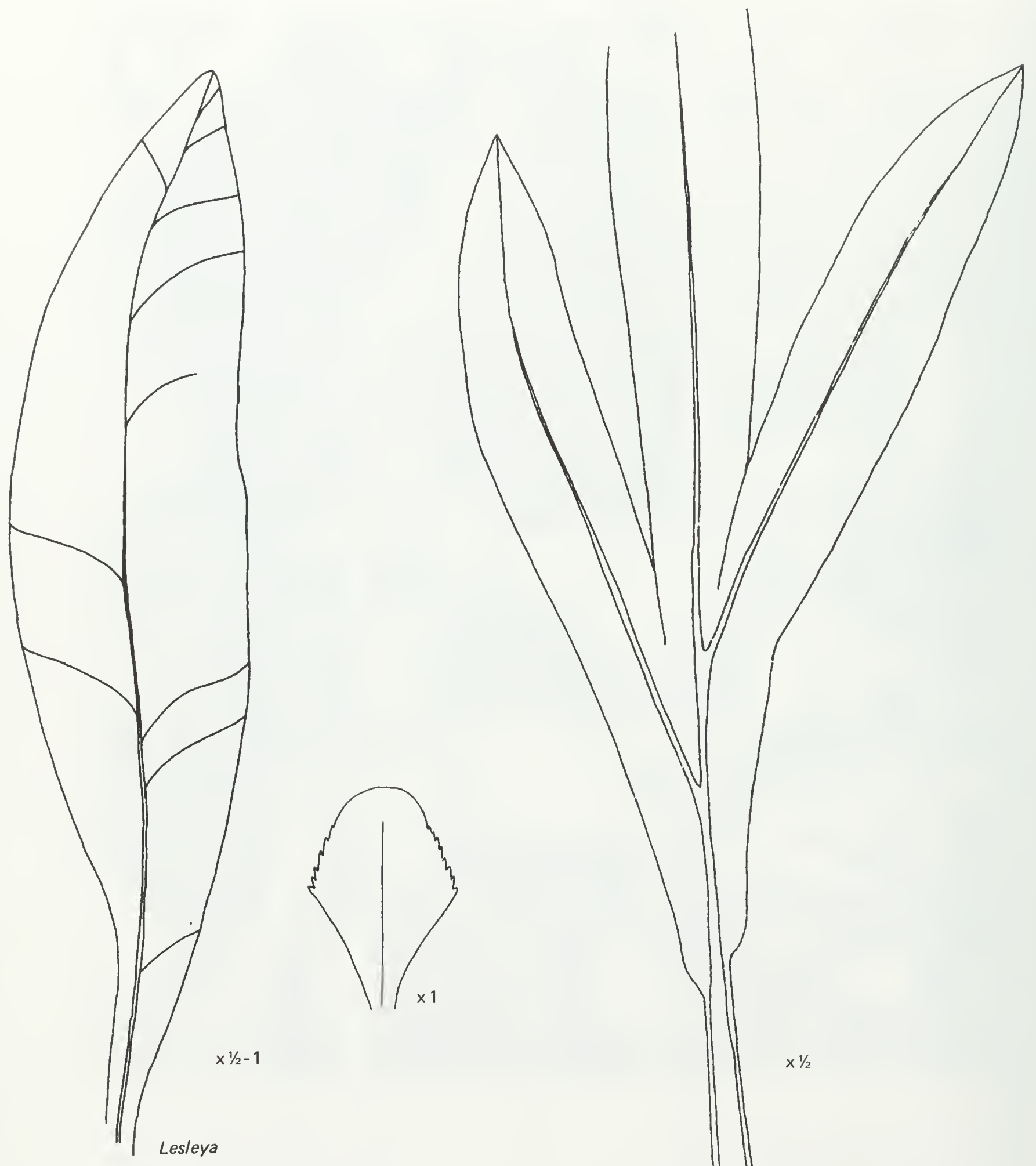

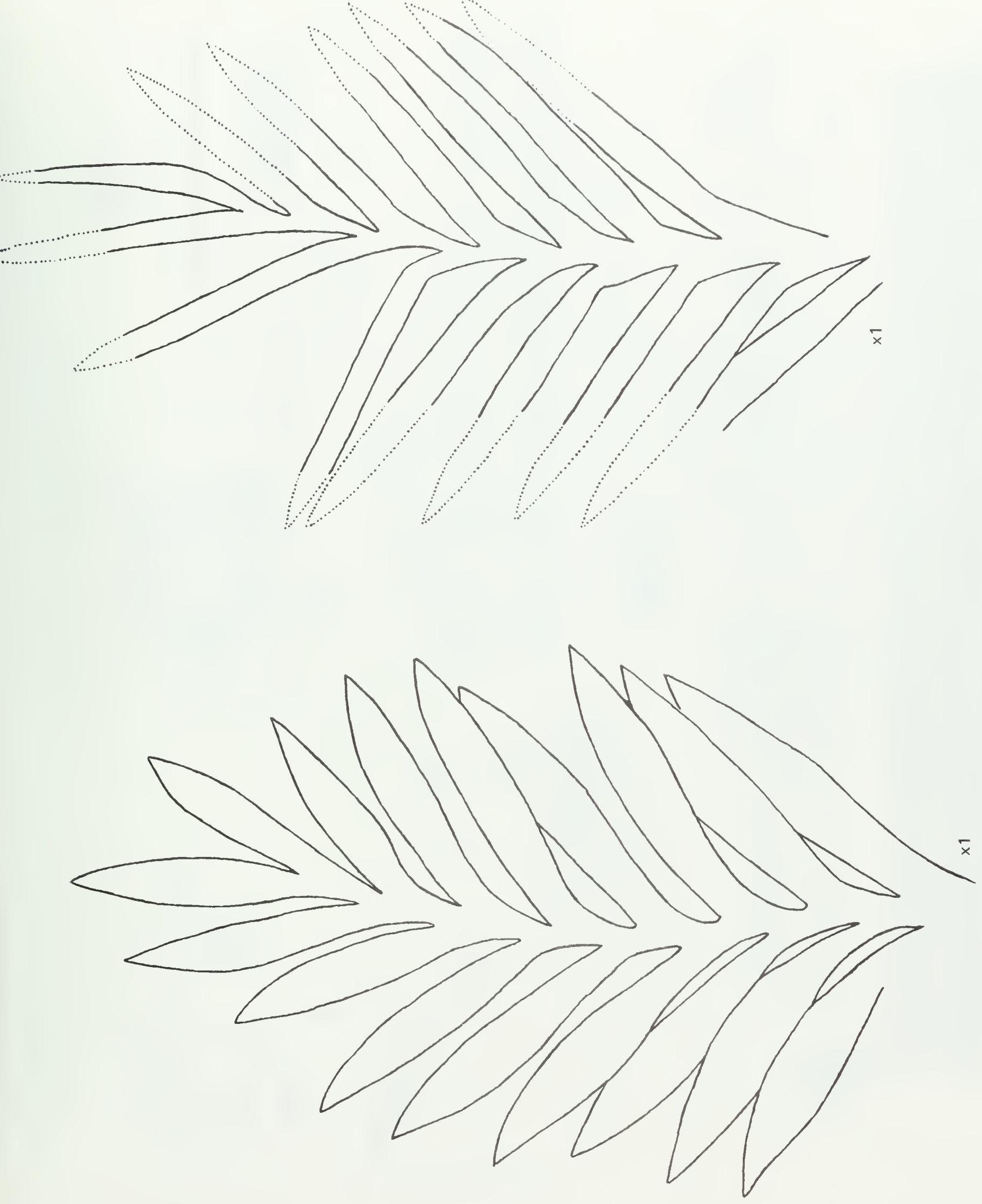
Leary: Pennsylvanian Flora, Rock Island County, Illinois

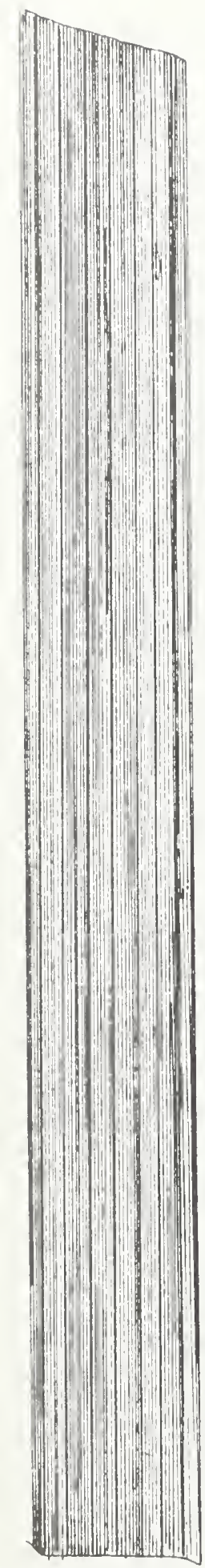

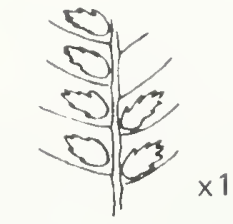

Cordaianthus
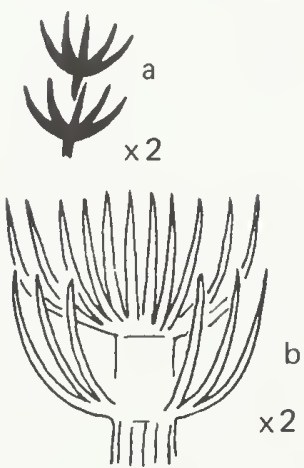

Asterophyllites
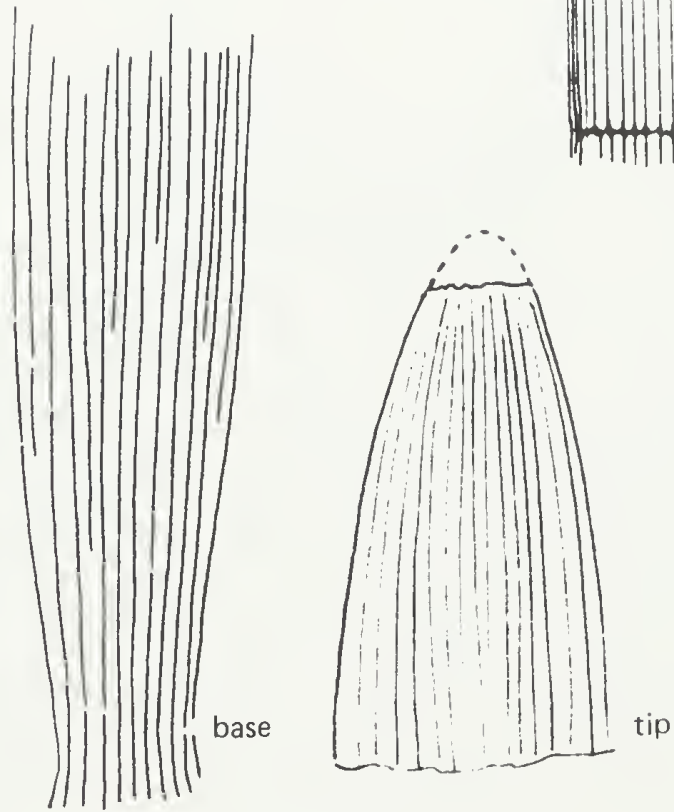

Cordaites

$\times 1-x .5$
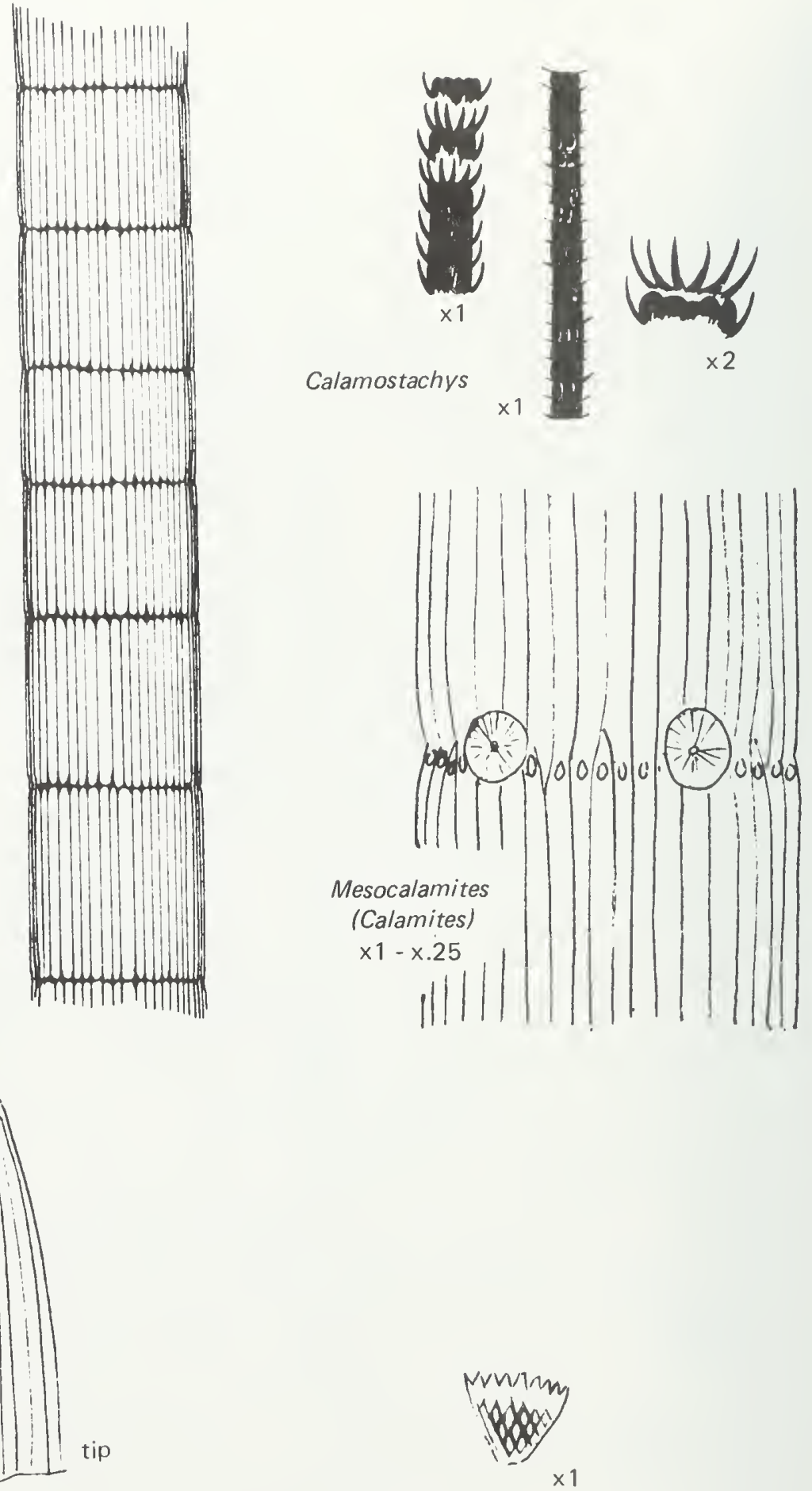

Lacoea

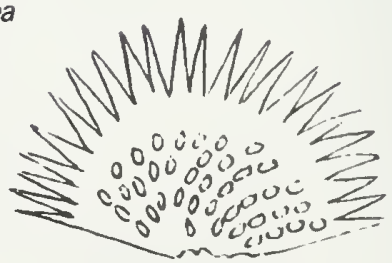



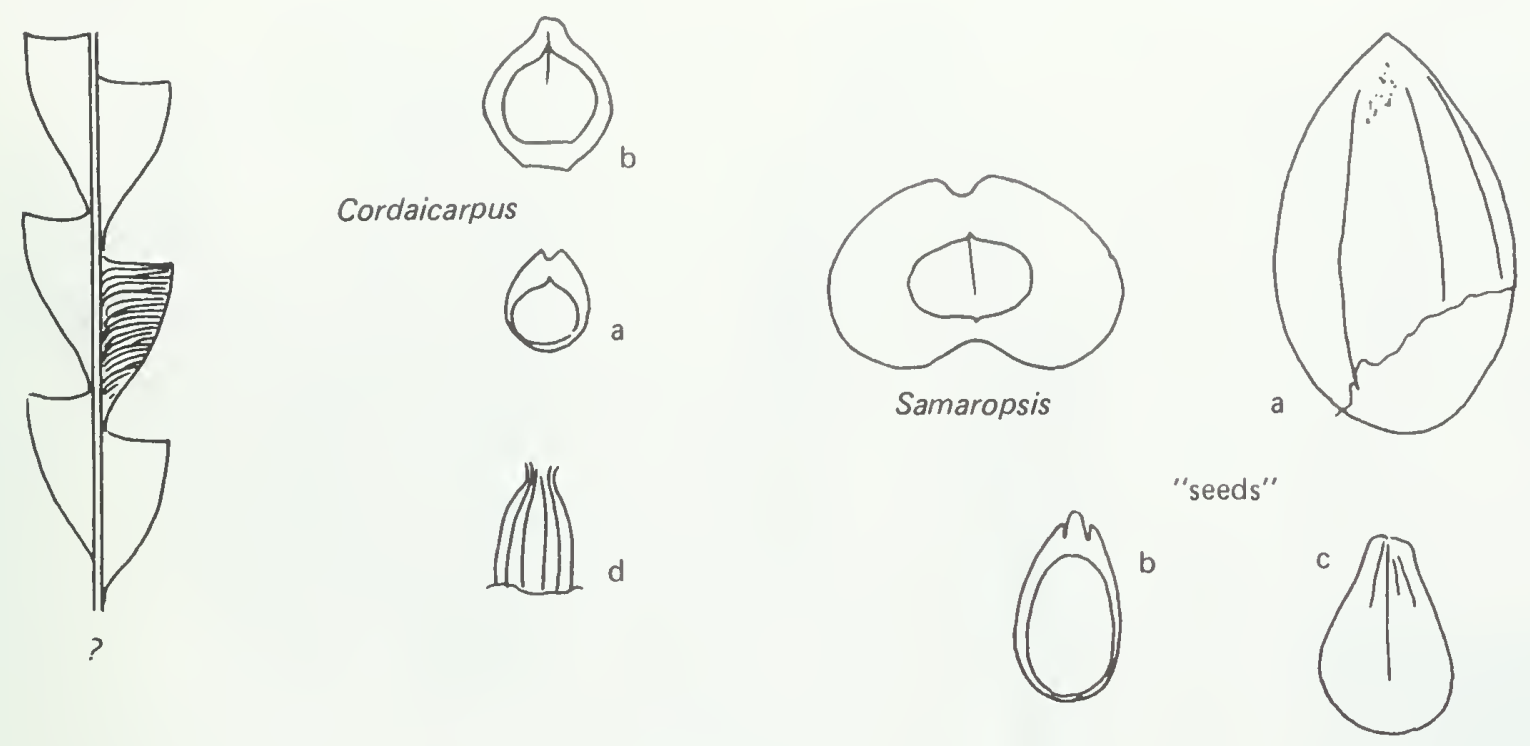

Telangium

cecy is

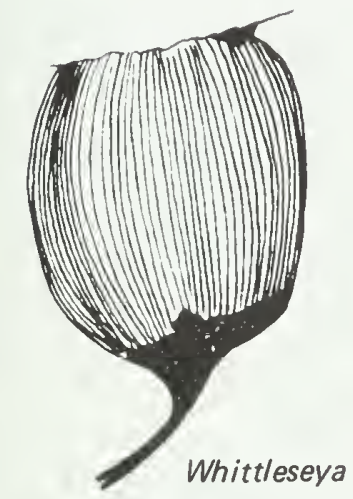

$\times 1$
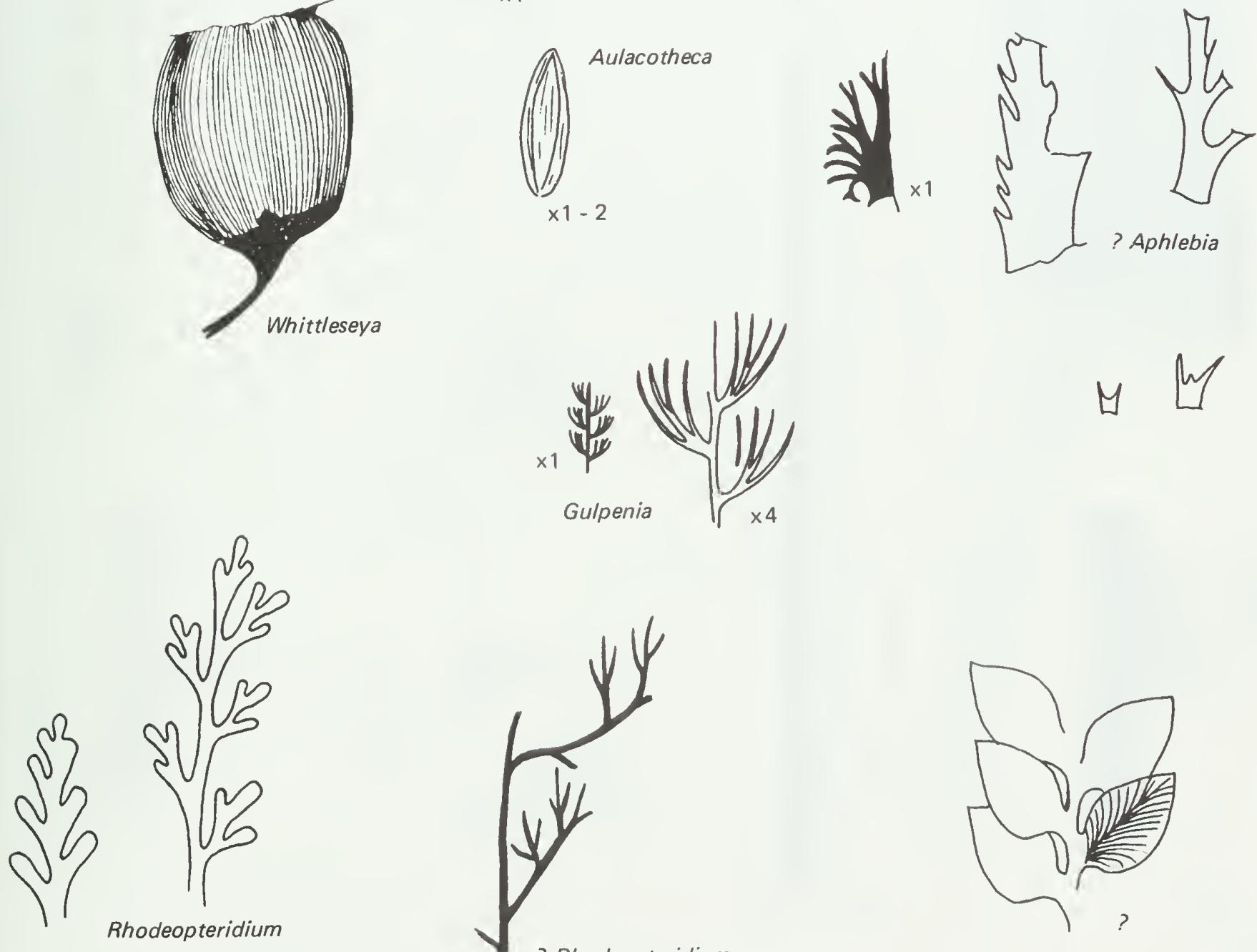

Rhodeopteridium
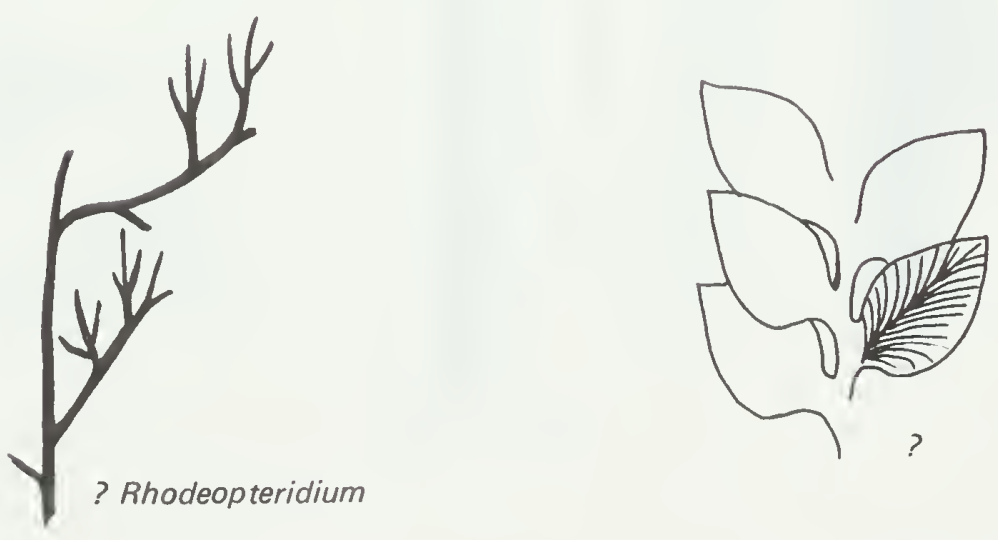

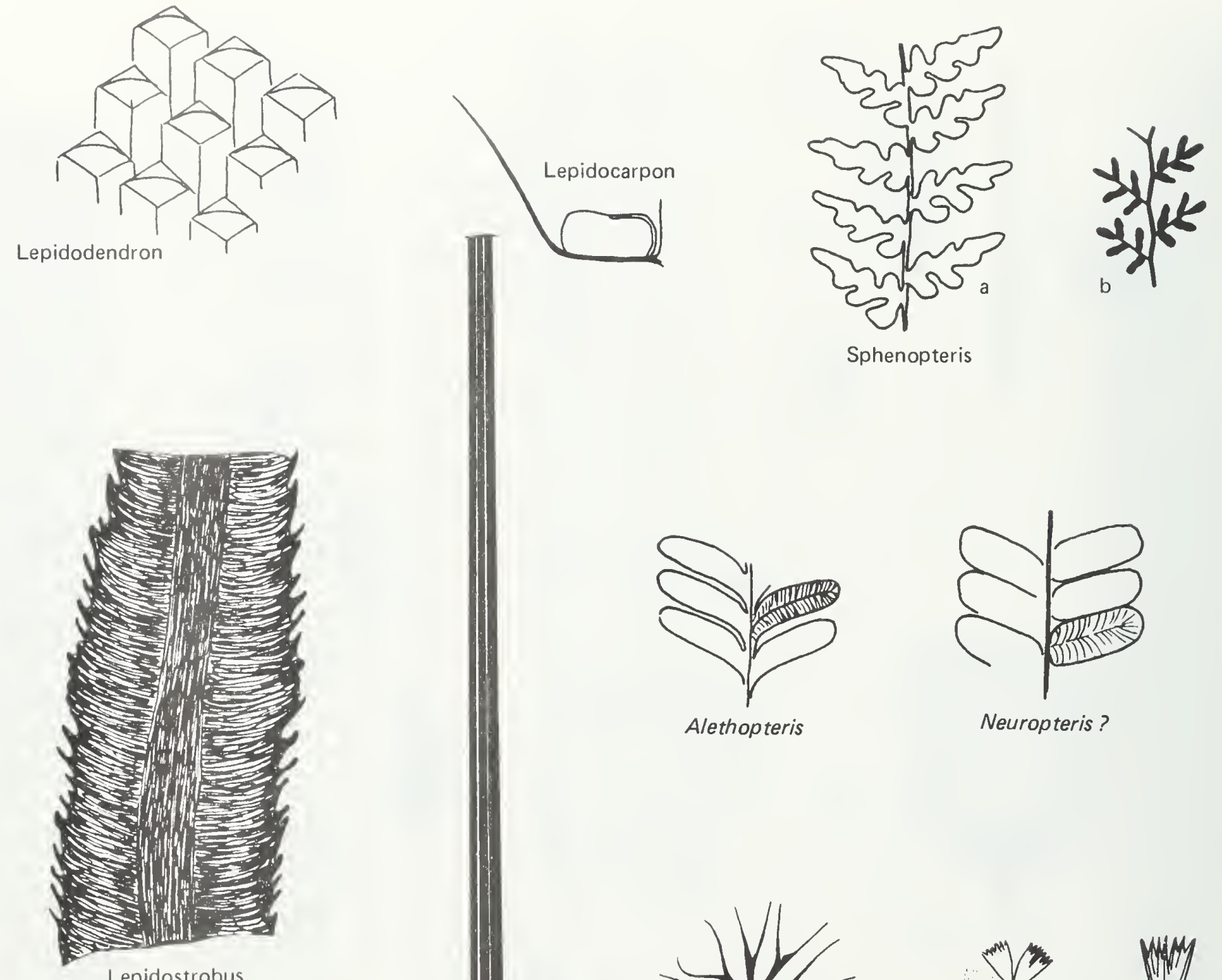

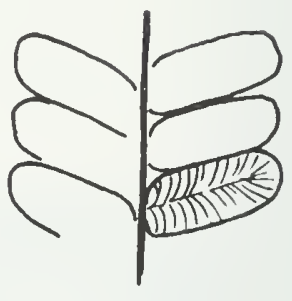

Alethopteris

Neuropteris?

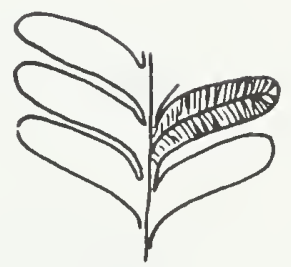

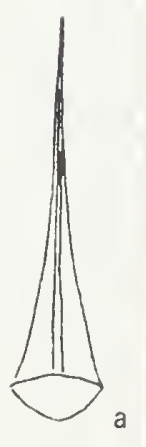

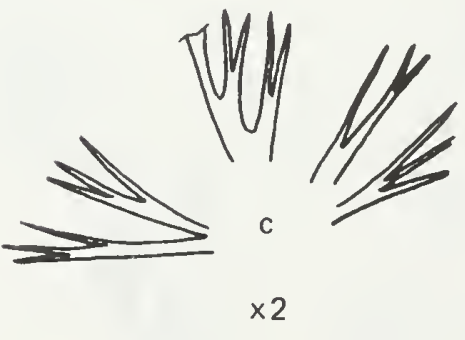

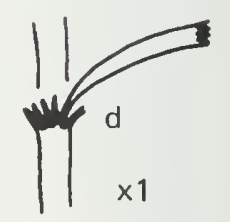



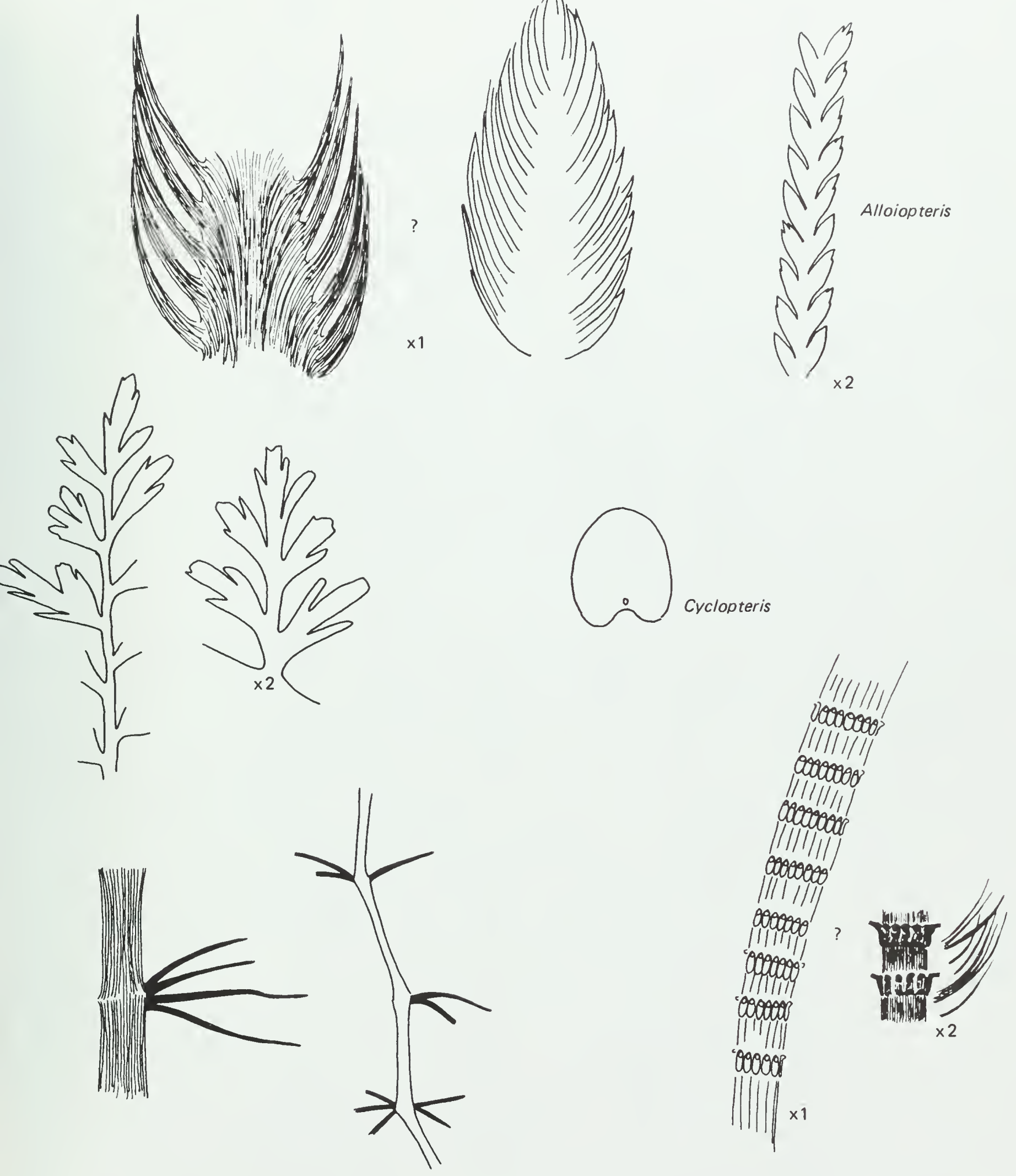


\section{ACKNOWLEDGEMENTS}

Many people have helped in the preparation of this field trip. The organizers of the International Carboniferous Congress have cooperated with the author in planning and publicizing the trip. Dr. Tom L. Phillips, as chairman in charge of one-day field trips, has helped with arrangements. Roy Nelson, supervisor of the Allied Stone Company quarry, Richard DeSchepper, supervisor of the Collinson Stone Company quarry, and Howard Dixon, geologist with Moline Consumers, made access to the quarries possible. Special thanks go to them for their continued cooperation without which research at these sites would be impossible.

Parts of the text and some of the illustrations used in this guide were taken from guidebooks of the Illinois State Geological Survey and the guidebook for the 31st Tri-State Field Conference (1967). The author appreciates permission to use this information. The author also gratefully acknowledges the assistance, comments, and suggestions given by staff members of the Illinois State Geological Survey and faculty at the University of Illinois and at Augustana College. 

